\title{
Emission sources contributing to tropospheric ozone over Equatorial Africa during the summer monsoon
}

\author{
I. Bouarar ${ }^{1}$, K. S. Law ${ }^{1}$, M. Pham ${ }^{1}$, C. Liousse ${ }^{2}$, H. Schlager ${ }^{3}$, T. Hamburger ${ }^{3}$, C. E.Reeves ${ }^{4}$, J.-P. Cammas ${ }^{2}$, \\ P. Nédéléc ${ }^{2}$, S. Szopa ${ }^{5}$, F. Ravegnani ${ }^{6}$, S. Viciani ${ }^{7}$, F. D'Amato ${ }^{7}$, A. Ulanovsky ${ }^{8}$, and A. Richter ${ }^{9}$ \\ ${ }^{1}$ UPMC Université Paris 06: Université Versailles Saint-Quentin: CNRS/INSU; UMR8190, LATMOS/IPSL, Paris, France \\ ${ }^{2}$ Université de Toulouse, UPS, LA (Laboratoire d'Aerologie), CNRS UMR5560, Toulouse, France \\ ${ }^{3}$ DLR Institut für Physik der Atmosphäre, Oberpfaffenhofen, Germay \\ ${ }^{4}$ School of Environmental Sciences, University of East Anglia, Norwich, UK \\ ${ }^{5}$ Laboratoire des Sciences du Climat et de l'Environnement, LSCE/IPSL, Saclay, France \\ ${ }^{6}$ Instituto di Scienze dell'Atmosfera e del Clima, Consiglio Nazionale delle Ricerche (ISAC-CNR), Italy \\ ${ }^{7}$ Consiglio Nazionale dell Ricerche-Istituto Nazionale di Ottica (CNR-INO), Firenze, Italy \\ ${ }^{8}$ Central Aerological Observatory, Moscow, Russia \\ ${ }^{8}$ Institute of Environmental Physics, University of Bremen, Bremen, Germany
}

Received: 27 December 2010 - Published in Atmos. Chem. Phys. Discuss.: 5 May 2011

Revised: 11 November 2011 - Accepted: 15 November 2011 - Published: 22 December 2011

\begin{abstract}
A global chemistry-climate model LMDz_INCA is used to investigate the contribution of African and Asian emissions to tropospheric ozone over Central and West Africa during the summer monsoon. The model results show that ozone in this region is most sensitive to lightning $\mathrm{NO}_{\mathrm{x}}$ and to Central African biomass burning emissions. However, other emission categories also contribute significantly to regional ozone. The maximum ozone changes due to lightning $\mathrm{NO}_{\mathrm{x}}$ occur in the upper troposphere between $400 \mathrm{hPa}$ and $200 \mathrm{hPa}$ over West Africa and downwind over the Atlantic Ocean. Biomass burning emissions mainly influence ozone in the lower and middle troposphere over Central Africa, and downwind due to westward transport. Biogenic emissions of volatile organic compounds, which can be uplifted from the lower troposphere to higher altitudes by the deep convection that occurs over West Africa during the monsoon season, lead to maximum ozone changes in the lower stratosphere region. Soil $\mathrm{NO}_{\mathrm{x}}$ emissions over the Sahel region make a significant contribution to ozone in the lower troposphere. In addition, convective uplift of these emissions and subsequent ozone production are also an important source of ozone in the upper troposphere over West Africa. Concerning African
\end{abstract}

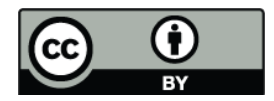

Correspondence to: I. Bouarar (idir.bouarar@latmos.ipsl.fr) anthropogenic emissions, they only make a small contribution to ozone compared to the other emission categories. The model results indicate that most ozone changes due to African emissions occur downwind, especially over the Atlantic Ocean, far from the emission regions. The import of Asian emissions also makes a considerable contribution to ozone concentrations above $150 \mathrm{hPa}$ and has to be taken into account in studies of the ozone budget over Africa. Using IPCC AR5 (Intergovernmental Panel on Climate Change; Fifth Assessment Report) estimates of anthropogenic emissions for 2030 over Africa and Asia, model calculations show larger changes in ozone over Africa due to growth in Asian emissions compared to African emissions over the next $20 \mathrm{yr}$.

\section{Introduction}

Tropospheric ozone $\left(\mathrm{O}_{3}\right)$ plays an important role in the global climate and chemical composition of the atmosphere. Indeed, the greenhouse forcing of tropospheric ozone affects the radiation budget of the atmosphere (Forster et al., 2007). Moreover, ozone is an important source of hydroxyl $(\mathrm{OH})$ radicals which determine to a large extent the removal and atmospheric lifetime of many trace gases (Brasseur et al., 1999; Jacob, 1999). Ozone production in the troposphere is controlled by transport from the $\mathrm{O}_{3}$-rich stratosphere (Olsen et al., 2002) and by photochemical oxidation of

Published by Copernicus Publications on behalf of the European Geosciences Union. 
carbon monoxide $(\mathrm{CO})$, methane $\left(\mathrm{CH}_{4}\right)$ and other volatile organic compounds (VOCs) in the presence of nitrogen oxides $\left(\mathrm{NO}_{\mathrm{x}}=\mathrm{NO}+\mathrm{NO}_{2}\right)($ Crutzen, 1974; Atkinson, 2000). It is removed by photochemical loss and dry deposition.

Africa is an important source region for $\mathrm{O}_{3}$ precursors (Marufu et al., 2000; Jaeglé et al., 2004, 2005; Sauvage et al., 2005, 2007a; Stewart et al., 2008). It emits a large amount of biomass burning (BB) emissions ( $\mathrm{CO}, \mathrm{NO}_{\mathrm{x}}$, VOCs) associated with savanna and forest fires, which take place during dry (December to February, DJF) and monsoon (June to August, JJA) periods over West and Central Africa respectively, as well as with agricultural waste and domestic biofuel combustion (Crutzen and Andreae, 1990; Sauvage et al., 2005; Jonquières et al., 1998). Furthermore, vegetation and soils are also considered to be important sources of $\mathrm{O}_{3}$ precursors over Africa (Aghedo et al., 2007; Jaeglé et al., 2004). Forests and savanna near African Equatorial regions release large amounts of VOCs (Murphy et al., 2010; Ferreira et al., 2010), particularly isoprene, terpenes and methanol which are the dominant VOC emissions from vegetation. Important amounts of nitric oxide (NO) are emitted by soils after rainfall events over the Sahel region during the summer monsoon (Stewart et al., 2008). Analysis of satellite $\mathrm{NO}_{2}$ data by Jaeglé et al. (2005) showed enhancements in $\mathrm{NO}_{2}$ columns over this region during the monsoon season also attributed to rain-induced emissions of $\mathrm{NO}_{\mathrm{x}}$ from soils. Using surface $\mathrm{NO}_{2}$ data collected over Banizoumbou (Niger) between 1998 and 2004, Galy-Lacaux et al. (2009) also showed increased $\mathrm{NO}_{2}$ concentrations during the monsoon season. African cities along the southern coast and industrialized countries (e.g. Nigeria) release important amounts of anthropogenic emissions (Hopkins et al., 2009), related to oil gas exploration, which can influence $\mathrm{O}_{3}$ regionally (Minga et al., 2010).

Dynamical processes strongly influence ozone and precursor distributions in the African troposphere. During the Northern Hemisphere summer monsoon season, West Africa is marked by intense convective activity that occurs around the Inter Tropical Convergence Zone (ITCZ) around $10^{\circ} \mathrm{N}$. The resulting mesoscale convective systems (MCSs) lead to vertical transport of air masses, more or less influenced by local emissions, into the upper troposphere (UT) where chemical species have longer lifetimes and can be redistributed globally by prevailing westward winds. Using aircraft measurements performed in the framework of the African Monsoon Multidisciplinary Analyses (AMMA) project, Law et al. (2010) showed clear signatures of convective uplift of CO and aerosols into the tropical tropopause layer (TTL). Results from Bechara et al. (2010) also pointed to convection as an explanation for observed enhancements of VOCs in the UT over West Africa. Moreover, Sauvage et al. (2007b, c) and Barret et al. (2010) demonstrated that convection leads to production of important amounts of $\mathrm{NO}_{\mathrm{x}}$ from lightning in the UT which subsequently leads to $\mathrm{O}_{3}$ production downwind.
During the summer monsoon, BB emissions occur mostly south of the Equator over Central Africa. Nevertheless, cross-hemispheric transport of these emissions into West Africa has been shown to occur particularly during phases when the southern branch of the African Easterly Jet (AEJ) is active (Mari et al., 2008). This allows transport of BB pollutants towards the southern coast of West Africa (Williams et al., 2010b; Reeves et al., 2010) in the lower/mid troposphere. BB pollution can also be transported northwards into active convective regions over Chad/Sudan where they can be uplifted into the UT and transported westwards. Evidence for this pathway was found in analysis of aircraft data collected in the UT over West Africa (Real et al., 2010; Law et al., 2010). Recent studies have suggested an important role for import of Asian emissions on the chemical composition of the African UT during boreal summer (Sudo and Akimodo, 2007; Barret et al., 2008; Liu et al., 2009; Law et al., 2010). As shown for example by Park et al. (2009), convection associated with the Indian monsoon leads to injection of Asian trace gases into the UT. The Tropical Easterly Jet (TEJ) at $200 \mathrm{hPa}$ that extends into the Atlantic Ocean (Janicot et al., 2008) allows rapid westward transport of Asian pollution to West Africa. Sudo and Akimodo (2007) and Liu et al. (2009) analysed transport of tagged Asian $\mathrm{O}_{3}$ tracers in their global models. Both studies showed $\mathrm{O}_{3}$ outflow in the UT from Asia towards Africa. Analysis of pathways of intercontinental transport in summer performed within the HTAP (Hemispheric Transport of Air Pollution; see http://www.htap.org) project using passive $\mathrm{CO}$ tracers released over the northern hemisphere continents also confirmed that Asian pollution can reach the African UT (HTAP, 2010).

In this study, we examine the influence of different emissions on the distribution of tropospheric $\mathrm{O}_{3}$ over West and Central Africa as well as downwind over the Central Atlantic Ocean during the summer monsoon in 2006. For this purpose, we use the three-dimensional global chemistry model LMDz_INCA. Previous global modeling studies attempted to investigate the sensitivity of African tropospheric $\mathrm{O}_{3}$ to different emission sources at different times of year. For example, Marufu et al. (2000) calculated an annual average contribution of $16 \%$ from global $\mathrm{BB}$ emissions to tropospheric $\mathrm{O}_{3}$ over Africa for the year 1993. In a more recent study, Aghedo et al. (2007) examined the sensitivity of surface $\mathrm{O}_{3}$ and tropospheric $\mathrm{O}_{3}$ burden over Africa to different emissions. BB provided the largest impact on surface $\mathrm{O}_{3}$ concentrations during the monsoon season in their study. They also concluded that, in all seasons, African and global tropospheric $\mathrm{O}_{3}$ burdens are more sensitive to biogenic emissions than to $\mathrm{BB}$, lightning $\mathrm{NO}_{\mathrm{x}}(\mathrm{LiNOx}$ hereafter) and anthropogenic emissions. Williams et al. (2009) applied different biogenic emission inventories in a global model to assess the impact of such emissions from Africa on tropical tropospheric ozone in 2006. They found that differences in the seasonality and temporal distribution of the biogenic emissions used induce differences in the regional and global ozone simulated by 
their model. Recently, Barret et al. (2010) focused on the impact of LiNOx emissions on $\mathrm{O}_{3}$ in the UT over West Africa during the monsoon season. Based on results from several global chemical models, they showed the important impact of LiNOx on $\mathrm{O}_{3}$ (more than 10 ppbv production) occurring over the tropical Atlantic in agreement with Sauvage et al. (2007b).

Most previous modeling studies on the influence of African emissions were conducted either by focusing on a specific emission category or by switching off emissions one at a time. However, when turning off an emission source it is difficult to estimate its contribution to $\mathrm{O}_{3}$ due to non-linear effects (Wu et al., 2009; Grewe et al., 2010). In order to take into account such effects, our approach is based on the estimation of the influence of percentage reductions $(20 \%)$ in different African emissions on $\mathrm{O}_{3}$ within Equatorial Africa. In this study we also examine the impact of Asian emissions ( $20 \%$ reduction) on $\mathrm{O}_{3}$ over Africa which has largely been ignored in previous studies. Using emission estimates for 2030, we also estimate $\mathrm{O}_{3}$ changes due to growth in African and Asian anthropogenic emissions in the future. Results presented here are also compared to previous studies, where appropriate.

A brief description of the LMDz_INCA model is given in Sect. 2. Section 3 presents the model experiments and data used in this study. An evaluation of model performance against in-situ data from the AMMA and MOZAIC (Measurement of OZone and water vapour by Airbus In-service aircraft) programs as well as satellite measurements is presented in Sect. 4 with the aim of assessing the model's ability to model general features seen in the observations during the monsoon season. The results of the sensitivity studies to different emission reductions on $\mathrm{O}_{3}$ over Equatorial Africa are discussed in Sect. 5. In Sect. 6, we examine the possible impact of future emissions on West African chemical composition using anthropogenic emissions estimates for 2030 over Africa and Asia. Conclusions are given in Sect. 7.

\section{Model description}

The global chemistry-climate model LMDz_INCA couples the general circulation model LMDz (Laboratoire de Météorologie Dynamique, zoom) version 4 and version 3 of the INCA (Interactive Chemistry and Aerosols) chemistry module (Hauglustaine et al., 2004; Folberth et al., 2006; Szopa et al., 2007). The model simulations were performed with horizontal resolution of $3.75^{\circ}$ in longitude and $2.5^{\circ}$ in latitude $(96 \times 72$ grid cells) and 19 hybrid $(\sigma, \mathrm{p})$ vertical levels extending from the surface to $3 \mathrm{hPa}$. The vertical resolution is $300-500 \mathrm{~m}$ in the boundary layer and around $2 \mathrm{~km}$ at the tropopause with 7-9 levels located in the stratosphere and 2-3 levels in the TTL. In LMDz, large-scale advection of tracers is described according to a second order finite volume scheme (Van Leer, 1977; Hourdin and Armengaud, 1999). The surface boundary layer is treated according to Louis (1979). In this study, both the Tiedtke (1989) and Kerry Emanuel $(1991,1993)$ schemes were used for the parameterization of deep convection. The Emanuel scheme was chosen for the baseline simulation and Tiedtke scheme was used in a sensitivity run (see Sect. 3.2). Hourdin et al. (2006) provides a detailed description of the parameterizations in the dynamical part of the model.

The chemistry module INCA simulates tropospheric chemistry, wet scavenging and dry deposition of a number of chemical species (Folberth et al., 2006). It includes a comprehensive chemistry scheme including more than 80 species and 250 chemical reactions. When coupled to LMDz, the model can be used to calculate the distribution of tropospheric ozone and precursors considering emissions, transport, photochemical reactions, deposition and scavenging. The standard INCA chemical scheme is based on the $\mathrm{CH}_{4}-\mathrm{NO}_{\mathrm{x}}-\mathrm{CO}-\mathrm{O}_{3}$ photochemistry representative of the background chemistry of the troposphere (Hauglustaine et al., 2004). For the present study we have used the INCA_NMHC version (Folberth et al. 2006) which also includes an oxidation scheme for volatile organic compounds (VOCs) (e.g. ethane, propane, isoprene, terpenes) and their products. Dry deposition of chemical species (e.g. $\mathrm{O}_{3}, \mathrm{HNO}_{3}, \mathrm{HNO}_{4}, \mathrm{CO}, \mathrm{HCHO}$ ) at the surface is based on the resistance-in-series approach (Wesely, 1989; Walmsley and Wesely, 1996; Wesely and Hicks, 2000). Wet scavenging of soluble species (e.g. $\mathrm{HNO}_{3}, \mathrm{H}_{2} \mathrm{O}_{2}, \mathrm{HCHO}$ and $\mathrm{HNO}_{4}$ ) is parameterized with a first-order loss process as originally proposed by Giorgi and Chameides (1985). Folberth et al. (2006) provide a more detailed description of dry deposition and wet scavenging parameterizations in LMDz_INCA.

Concerning surface emissions, the RETRO anthropogenic emissions of $\mathrm{CO}, \mathrm{NO}_{\mathrm{x}}$ and VOCs for the year 2000 were used with emissions provided for different source sectors (e.g. residential and industrial combustion, road transport, solvent use and agriculture and land use change). Details about the chemical compounds emitted as well as categorization of source sectors can be found on the RETRO website (http://retro.enes.org). Monthly average biomass burning emissions for 2006 were taken from the GFEDv2 (Global Fire Emissions Database, version 2) inventory (Van der Werf et al., 2006). In addition, recent biomass burning and anthropogenic emissions estimates developed in the framework of the AMMA project (Liousse et al., 2008, 2010), were also used over Africa (hereafter referred to as L3JRC inventory). Table 3 shows integrated biomass burning emissions totals for $\mathrm{CO}$ and $\mathrm{NO}_{\mathrm{x}}$ over Africa in the L3JRC and GFEDv2 inventories. These emissions are higher in the L3JRC inventory by around $47 \%$ and $61 \%$ respectively in 2006 (and $70 \%$ and $75 \%$ respectively during the summer (JJA) period) compared to GFEDv2. Biomass burning emissions were emitted at the surface in the model simulations presented in this study (see Table 1). 
NO emissions from lightning, fixed to a total global amount of $5 \mathrm{TgNyr}^{-1}$ are calculated interactively in LMDz_INCA on the basis of the occurrence of convection and cloud top heights (Jourdain and Hauglustaine, 2001). Biogenic emissions of isoprene, terpenes, methanol, acetone and $\mathrm{NO}$ were prepared using the inventory derived from the dynamical vegetation model ORCHIDEE (Lathière et al., 2006). Other biogenic emissions (e.g. oceanic emissions) and other VOC emissions were taken from the GEIA (Global Emissions Inventory Activity) database (http://www. geiacenter.org).

\section{Evaluation data and model simulations}

In this section, we present the data used to evaluate model performance (Sect. 4) and a description of the model simulations and sensitivity studies. Data from the satellite instruments MOPITT (Measurement Of Pollution In The Troposphere) and SCIAMACHY (Scanning Imaging Absorption spectrometer for Atmospheric CHartographY), and aircraft measurements from the AMMA and MOZAIC programs are presented in the first section. Model simulations and sensitivity studies are presented in Sect. 3.2.

\subsection{Satellite and in-situ data}

\subsubsection{MOPITT and SCIAMACHY observations}

The MOPITT instrument is flying on board the NASA Terra satellite and has been operational since March 2000 (Drummond and Mand, 1996; Deeter et al., 2004). It measures upwelling radiation in the thermal infrared spectral range using gas-filter correlation radiometry. At nadir view, MOPITT offers a horizontal resolution of $22 \times 22 \mathrm{~km}^{2}$ and allows global coverage in two to three days. MOPITT data used in this study corresponds to the daytime CO total columns observed during August 2006, and the Level 2 Version 3 product (Emmons et al., 2007, 2009).

SCIAMACHY was launched in March 2002 on board the ENVISAT satellite and allows global measurements of a number of trace gases in the troposphere and stratosphere with $30 \times 60 \mathrm{~km}^{2}$ resolution (Bovensmann et al., 1999). We use the $\mathrm{NO}_{2}$ tropospheric columns for August 2006 based on the DOAS (Differential Optical Absorption Spectroscopy) retrieval algorithm (Richter et al, 2005).

In order to compare LMDz_INCA results to MOPITT and SCIAMACHY observations, the modelled $\mathrm{CO}$ and $\mathrm{NO}_{2}$ columns in each grid cell were calculated at the local overpass time of each instrument $(10 \mathrm{~h}: 30 \mathrm{~min}$ and $10 \mathrm{~h}$ respectively). This calculation is essential knowing the important diurnal variation of $\mathrm{NO}_{2}$ concentrations in the troposphere. Moreover, for a proper comparison with MOPITT, the model CO total columns were calculated by applying the MOPITT Averaging Kernels. Details about the calculation and method are given in Rodgers and Connor (2003) and Deeter et al. (2004).

\subsubsection{AMMA measurements}

The in-situ measurements performed during AMMA and considered in this study were made aboard five research aircraft: the M55 Geophysica and DLR Falcon (DF20) were based in Ouagadougou (Burkina Faso); the French Falcon (FF20), ATR42, and United Kingdom FAAM (Facility for Airborne Atmospheric Measurements) BAe-146 were based in Niamey (Niger). The measurements presented here were made during the special observation period in July and $\mathrm{Au}-$ gust 2006. Chemical measurements of ozone and precursors (e.g. $\mathrm{CO}, \mathrm{NO}_{\mathrm{x}}, \mathrm{HCHO}$, isoprene etc.) and also aerosols were made over West Africa in the boundary layer and up to the lower stratosphere allowing a comprehensive characterization of the chemical composition of the troposphere during the monsoon season. A detailed description of the field campaign and aircraft payloads is given in Reeves et al. (2010). In order to compare LMDz_INCA simulations to the AMMA measurements, the model results were interpolated along flight tracks and compared to 1 min averaged observations.

\subsubsection{MOZAIC observations}

Daily in-situ measurements of $\mathrm{CO}$ and $\mathrm{O}_{3}$ were collected in the framework of MOZAIC (Marenco et al., 1998) using commercial aircraft in August 2006. Figure 1 shows aircraft flight routes between Windhoek $\left(22.5^{\circ} \mathrm{S}, 17.5^{\circ} \mathrm{E}\right.$, Namibia) and Frankfurt (50 $\mathrm{N}, 8.6^{\circ} \mathrm{E}$, Germany) and London $\left(51.15^{\circ} \mathrm{N}-0.19^{\circ} \mathrm{W}\right.$, UK). In order to have sufficient data for statistical comparisons we selected data recorded at flight altitudes above $250 \mathrm{hPa}$. At cruise altitudes, the MOZAIC data are interesting insofar as they were measured over the biomass burning regions of Central Africa and over West Africa. These data provide complementary information about the distribution of $\mathrm{CO}$ and $\mathrm{O}_{3}$ in the upper troposphere. The same interpolation method used for the LMDz INCA versus AMMA data comparison (interpolation to a 1 minute averaged observation times and locations) was also performed.

\subsection{Model simulations}

LMDz_INCA was used to perform different simulations for 2006 in order to investigate the impact of emissions on tropospheric $\mathrm{O}_{3}$ over Equatorial Africa. The simulations (see Table 1) consisted of a control simulation (KE_AMMA) and a set of sensitivity experiments. For a better comparison with satellite and in-situ data, the model was nudged with wind fields from the ECMWF (European Centre for MediumRange Weather Forecasts) analyses for 2006. The control run KE_AMMA was performed using the Kerry Emanuel (KE) convection scheme. A one year spin-up was conducted from January to December 2005 before the 2006 run. 
Table 1. Description of the LMDz_INCA simulations and sensitivity experiments used in this study. The $20 \%$ perturbations to African emissions were performed between $35^{\circ} \mathrm{S}-20^{\circ} \mathrm{N}$ and $20^{\circ} \mathrm{W}-40^{\circ} \mathrm{E}$ (see Fig. 1). Changes in emission totals over this region and Asia are also provided.

\begin{tabular}{|c|c|c|}
\hline Model simulation & Description & $\begin{array}{l}\text { Emission changes in } \\
\text { sensitivity studies ( } \mathrm{Tg} \text { ) }\end{array}$ \\
\hline KE_AMMA & Control run based on the Emanuel (1993) convection scheme & \\
\hline LiNOx_red & Lightning emissions reduced by $20 \%$ & $-0.23 \mathrm{TgN}$ \\
\hline BB_red & Biomass burning emissions reduced by $20 \%$ & $-0.62 \mathrm{Tg} \mathrm{N} ;-16.17 \mathrm{Tg} \mathrm{C}$ \\
\hline BIO_red & Biogenic VOCs reduced by $20 \%$ & $-5.88 \mathrm{TgC}$ \\
\hline SNOx_red & Soil $\mathrm{NO}_{\mathrm{x}}$ emissions reduced by $20 \%$ & $-0.16 \mathrm{Tg} \mathrm{N}$ \\
\hline ANTH_red & Anthropogenic emissions reduced by $20 \%$ & $-0.06 \mathrm{Tg} \mathrm{N} ;-1.36 \mathrm{TgC}$ \\
\hline ASIA_red & Asian emissions $\left(70^{\circ} \mathrm{E}-120^{\circ} \mathrm{E}, 10^{\circ} \mathrm{S}-40^{\circ} \mathrm{N}\right)$ reduced by $20 \%$ & $-0.4 \mathrm{TgN} ;-10.4 \mathrm{Tg} \mathrm{C}$ \\
\hline XLiNOx & Lightning emissions increased by $50 \%$ & $+0.58 \mathrm{Tg} \mathrm{N}$ \\
\hline Conv_off & Convective transport and lightning $\mathrm{NO}_{\mathrm{x}}$ switched off over Africa & \\
\hline TI_AMMA & Simulation using the Tiedtke (1989) convection scheme & \\
\hline INCA_2030 & $\begin{array}{l}\text { Simulation using anthropogenic emissions } \\
\text { over Africa and Asia from the IPCC RCP45 } \\
\text { scenario for } 2030\end{array}$ & See Table 2 \\
\hline
\end{tabular}

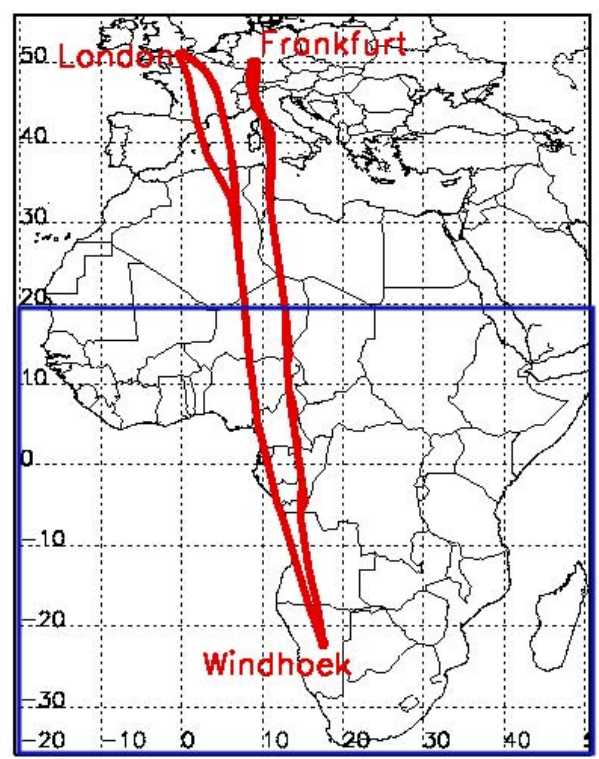

Fig. 1. MOZAIC aircraft flight tracks (in red) between Windhoek $\left(22.5^{\circ} \mathrm{S}-17.5^{\circ} \mathrm{E}\right.$, Namibia) and Frankfurt $\left(50^{\circ} \mathrm{N}-8.6^{\circ} \mathrm{E}\right.$, Germany) and London $\left(51.15^{\circ} \mathrm{N}-0.19^{\circ} \mathrm{W}, \mathrm{UK}\right)$ in August 2006. The blue square indicates the region where emissions were reduced by $20 \%$ in the sensitivity studies (see text and Table 1 for details).

The sensitivity experiments were carried out from May to September 2006 using restart files from the KE_AMMA simulation and were compared with this simulation in order to examine the sensitivity of tropospheric $\mathrm{O}_{3}$ over Equatorial Africa to reductions in different emissions. In the LiNOx_red, SNOx_red, BIO_red, ANTH_red and BB_red ex- periments, respectively, the lightning $\mathrm{NO}_{\mathrm{x}}$, soil $\mathrm{NO}_{\mathrm{x}}$, biogenic VOCs, anthropogenic and biomass burning emissions were reduced by $20 \%$ over Africa between $35^{\circ} \mathrm{S}$ and $20^{\circ} \mathrm{N}$ (Fig. 1). The " $20 \%$ " perturbation is designed to account for nonlinear $\mathrm{O}_{3}$ chemistry. In fact, setting an emission source to zero may affect the lifetime of other species in the troposphere. For example, Wu et al. (2009) showed that the perturbation from $100 \% \mathrm{NO}_{\mathrm{x}}$ emission reduction results in $\mathrm{O}_{3}$ responses greater than 5 times $20 \%$ reductions. In the ASIA red test, the " $20 \%$ " perturbation included all the emission categories over Asia $\left(70^{\circ} \mathrm{E}-120^{\circ} \mathrm{E}, 10^{\circ} \mathrm{S}-40^{\circ} \mathrm{N}\right)$. The results of these sensitivity tests are discussed in Sect. 5. In order to evaluate the sensitivity of model results to convection, the Tiedtke (1989) scheme was also used in run TI_AMMA and convective transport of trace species was completely switched off in run Conv_off. Note that in Conv_off experiment, LiNOx emissions were also switched off since they are coupled to convection in the model.

\section{Model performance}

This section presents an evaluation of LMDz_INCA performance during summer 2006 through comparison with in-situ data from the AMMA and MOZAIC aircraft measurements and satellite observations from MOPITT and SCIAMACHY. Results from the KE_AMMA control run and relevant sensitivity simulations are discussed. This section aims to evaluate model performance in terms of broad signatures seen in the data particularly related to the impact of convection on chemical composition in the free troposphere and the redistribution of emission sources both vertically and horizontally. 

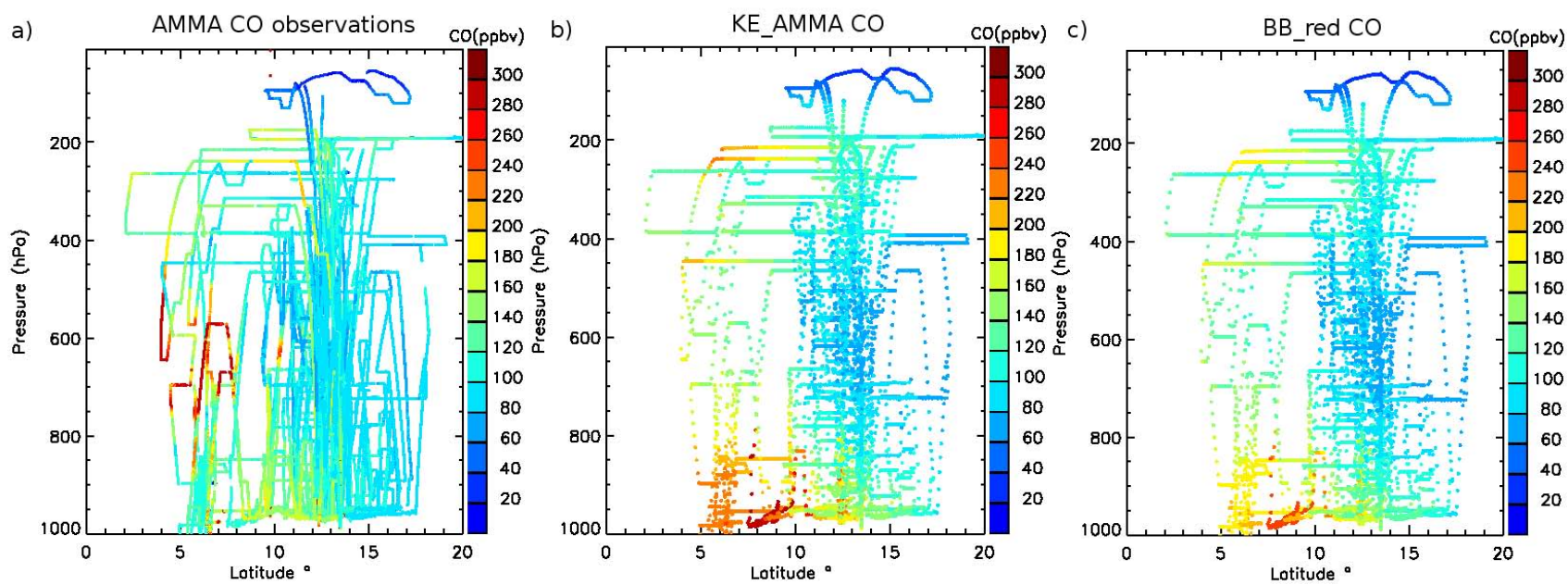

Fig. 2. Comparison of interpolated model output from KE_AMMA (b) and BB_red (c) simulations against CO observations (a) color coded in terms of $\mathrm{CO}$ in ppbv along the north-south flights during the AMMA campaign in July and August 2006.

A first evaluation of LMDz_INCA over West Africa was performed by Williams et al. (2010a) and Barret et al. (2010) as part of an AMMA multi-model comparison exercise. In those studies, results from the KE_AMMA simulation were compared to results from the chemistry transport models MOCAGE (Teyssèdre et al., 2007), TM4 (Dentener et al., 2003) and p-TOMCAT (Yang et al., 2005). Using passive CO tracers, Williams et al. (2010a) showed that differences in model transport parameterizations resulted in different distributions of tracers over Africa. Moreover, Barret et al. (2010) showed important differences between the models concerning the distribution of $\mathrm{CO}, \mathrm{O}_{3}$ and $\mathrm{NO}_{\mathrm{x}}$ in the UT which were explained by differences in convective parameterizations. These results are discussed further later in this section.

\subsection{Comparison with AMMA data}

Figure 2 shows a comparison of model results interpolated along flight tracks against $\mathrm{CO}$ measurements during the AMMA campaign. This figure gives an indication about the latitudinal distribution of $\mathrm{CO}$ over West Africa during July and August 2006. Maximum CO concentrations (up to 480 ppbv) were measured in the middle troposphere (MT) at $500-750 \mathrm{hPa}$ near the Gulf of Guinea $\left(4^{\circ} \mathrm{S}-8^{\circ} \mathrm{N}\right)$ as discussed by Reeves et al. (2010). Enhanced $\mathrm{O}_{3}$ concentrations (up to $135 \mathrm{ppbv}$ ) were also measured in this region and at the same altitudes as shown in Williams et al. (2010a). Similar $\mathrm{O}_{3}$ increases in the $\mathrm{MT}$ were found in $\mathrm{O}_{3}$ soundings performed over Cotonou, Benin $\left(6.2^{\circ} \mathrm{N}, 2.2^{\circ} \mathrm{E}\right)$ during the AMMA campaign (Thouret et al., 2009) and, previously, in MOZAIC measurements over Lagos $\left(6.6^{\circ} \mathrm{N}, 3.3^{\circ} \mathrm{E}\right)$ as discussed in Sauvage et al. (2005). These enhanced concentrations of $\mathrm{CO}$ and $\mathrm{O}_{3}$ have been attributed to direct transport of BB plumes in the MT from Central Africa (e.g. Real et al. 2010). Andrés-Hernández et al. (2009) showed that air masses sampled over Gulf of Guinea in the MT are aged and, therefore, could be transported from other regions such as West or Central Africa. Moreover, using back trajectories of air masses sampled over Cotonou below $4 \mathrm{~km}$, Ancellet et al. (2009) showed such layers originating from Central Africa in data collected by the FF20.

Enhanced CO concentrations ( $\sim 200 \mathrm{ppbv})$ were also measured in the UT (200-300 hPa) over West Africa and Gulf of Guinea by AMMA aircraft. Based on analysis of DLR measurements, Huntrieser et al. (2011) showed that convective uplift of local emissions over West Africa can have a significant impact on UT chemical composition thereby contributing to observed $\mathrm{CO}$ enhancements. As demonstrated by several studies (Stohl et al., 2002; Lawrence et al., 2003; Barret et al., 2008), westward transport of Asian pollution by the TEJ may also impact the composition of the African UT. Another contribution to enhanced CO may come from BB emissions over Central Africa which can be redistributed to the UT. In fact, occasional plumes were measured over Gulf of Guinea at $100-150 \mathrm{hPa}$ and attributed to uplift of Central African BB emissions into the UT (Real et al., 2010). In the next section we show that indeed the chemical composition of the UT over West Africa is not only influenced by convective transport of local emissions but also by Asian emissions and Central African BB emissions as discussed in a recent analysis of M55 data collected in the TTL (Law et al., 2010).

Figure 2 also shows results from the KE_AMMA simulation. The CO increases seen in the UT around $200 \mathrm{hPa}$ are reasonably well captured but slightly overestimated over the Gulf of Guinea. Comparison with MOZAIC data (see Sect. 4.2) also shows that the modelled CO in the UT is slightly overestimated over this region. The run with reduced BB emissions (BB red) (Fig. 2c) shows reduced CO concentrations in the UT as well as in the MT and LT compared 
to KE_AMMA. This indicates that, in the model, Central African BB emissions influence not only the MT but also the LT and UT over the Gulf of Guinea in agreement with findings in Real et al. (2010).

Williams et al. (2010b) also demonstrated, using the TM4 model, that the influence of BB emissions from Central Africa extends into West Africa and that the largest impact occurs over the southern coast of West Africa and the Gulf of Guinea below $500 \mathrm{hPa}$. In the LT, the KE_AMMA results give high $\mathrm{CO}$ concentrations south of $10^{\circ} \mathrm{N}$ but observed concentrations over the Gulf of Guinea are overestimated. The $\mathrm{CO}$ enhancements seen in the MT around $5^{\circ} \mathrm{N}$ are however underestimated by the model. Williams et al. (2010a) showed that LMDz_INCA, as well as other global models, simulate a maximum in $\mathrm{CO}$ and $\mathrm{O}_{3}$ in the MT around $0_{-}$ $5^{\circ} \mathrm{S}$, further south over Gulf of Guinea compared to the observations. Using an inert tracer defined over Central Africa, they demonstrated that transport in the models was too zonal extending into the Atlantic Ocean in the MT and not extending far enough northward over the Equator. In the case of LMDz_INCA, the simulated horizontal wind fields in the MT over the Gulf of Guinea are much more zonal compared to ECMWF analyses. Moreover, Williams et al. (2010b) also showed no direct transport of air in the MT from Central Africa to the Gulf of Guinea when ECMWF meteorological analyses were used to drive the TM4 model. They showed that using ECMWF analyses with additional assimilated radiosonde data taken during the AMMA campaign improved this direct transport of air to West Africa in the MT. Therefore, the weak northward transport of Central African air in the ECMWF meteorological analyses can partly explain the discrepancy between LMDz_INCA and the observations in the MT. Model results are also sensitive to treatments of injection of BB emissions (e.g. Labonne et al., 2007; Williams et al., 2010b). In fact, $\mathrm{CO}$ increases of up to $30 \mathrm{ppbv}$ were calculated in the MT over the Atlantic Ocean when African BB emissions were injected up to $3 \mathrm{~km}$ in LMDz_INCA. Williams et al. (2010b) also showed increases in CO concentrations over the Atlantic Ocean when BB emissions are injected from the surface to $4 \mathrm{~km}$ in TM4. This indicates an increase in westward export of such emissions out of Central Africa when emissions injection is included. Therefore, model performance could be improved through inclusion of more realistic schemes for BB emissions (e.g. Freitas et al., 2007; Rio et al., 2010) and using the ECMWF analyses assimilating the AMMA soundings.

In order to evaluate the influence of convection on the chemical composition of the troposphere over West Africa, aircraft $\mathrm{CO}, \mathrm{O}_{3}$ and $\mathrm{NO}$ data from the DLR, FF20 and M55 observations were separated into air masses recently impacted by convection (CONV) and those less impacted by recent local convection (NOCONV). The purpose of this analysis is, firstly, to examine the observations in terms of convective influence to see whether there are signatures in the chemical data of convective influence in air uplifted over the last
3-4 days compared to more aged air masses, and secondly, to asses the performance of LMDz_INCA over a region strongly influenced by deep convection on a daily basis. The aim is not to quantify the impact of individual MCS, which cannot be reproduced by a global model run at coarse resolution, but to examine whether such a model run with current convective parameterizations is capable of capturing broad features observed in air masses influenced by deep convection.

The FF20 data were separated according to flight type based on the analysis of Ancellet et al. (2009) who examined each flight in terms of proximity to MCS. The approach used to distinguish the two categories for the M55 data was based on analysis of ECMWF back-trajectories from the flights and METEOSAT cloud images (see Law et al., 2010 for details). Coincidences between back-trajectories and convective cloud tops (identified when cloud top radiance temperatures were below $200 \mathrm{~K}$ ) were used to identify whether the sampled air masses were recently in contact with an MCS or region of convective uplift over the previous few days. Law et al. (2010) estimated the percentage of air masses encountering an MCS and showed that at $200 \mathrm{hPa}$ large regions over Africa were constantly influenced by recent local convection during the campaign period in August 2006. The approach used for the DLR data was also based on analysis of METEOSAT cloud images and Lagrangian backward trajectories calculated using the LAGRANTO model (Wernli and Davies, 1997) during transport up to $10 \mathrm{~h}$ before each flight. For air mass ages of less than $10 \mathrm{~h}$, satellite imagery was used to examine the time since passage of recent MCS relative to the DLR position to identify air masses of the CONV category. These approaches serve to give an indication about which flights were more or less influenced by convection. Further detailed analysis based, for example on mesoscale model results can provide more detailed information. In the case of the M55 flights, Fierli et al. (2011) followed such an approach. Whilst they showed larger convective impact in terms of percentage contributions, their results were broadly consistent with the analysis of Law et al. (2010) using the methodology outlined above.

Figure 3 shows the observed and modelled $\mathrm{CO}, \mathrm{NO}_{\mathrm{x}}$ and $\mathrm{O}_{3}$ for convective and non-convective profiles. The observed CO exhibits more variability in the UT between $200-300 \mathrm{hPa}$ in the CONV case with maximum values of $\sim 200 \mathrm{ppbv}$, while the maximum is $\sim 150 \mathrm{ppbv}$ in the NOCONV case. Interestingly, the CONV profiles also show minimum $\mathrm{CO}$ concentrations measured in the UT with values of $\sim 50 \mathrm{ppbv}$ around $200 \mathrm{hPa}$. As shown in Fig. 2, CO data exhibit a latitudinal gradient in the LT with high values measured over the southern forests and anthropogenic emissions along the Gulf of Guinea coast (see also Saunois et al., 2009). The convective uplift of such CO-rich air masses can influence higher altitudes as discussed previously. On the other hand, uplift of CO-poor air can decrease $\mathrm{CO}$ in detrainment regions, particularly in the northern part of the region. This may explain lower $\mathrm{CO}$ concentrations measured in the UT in the 

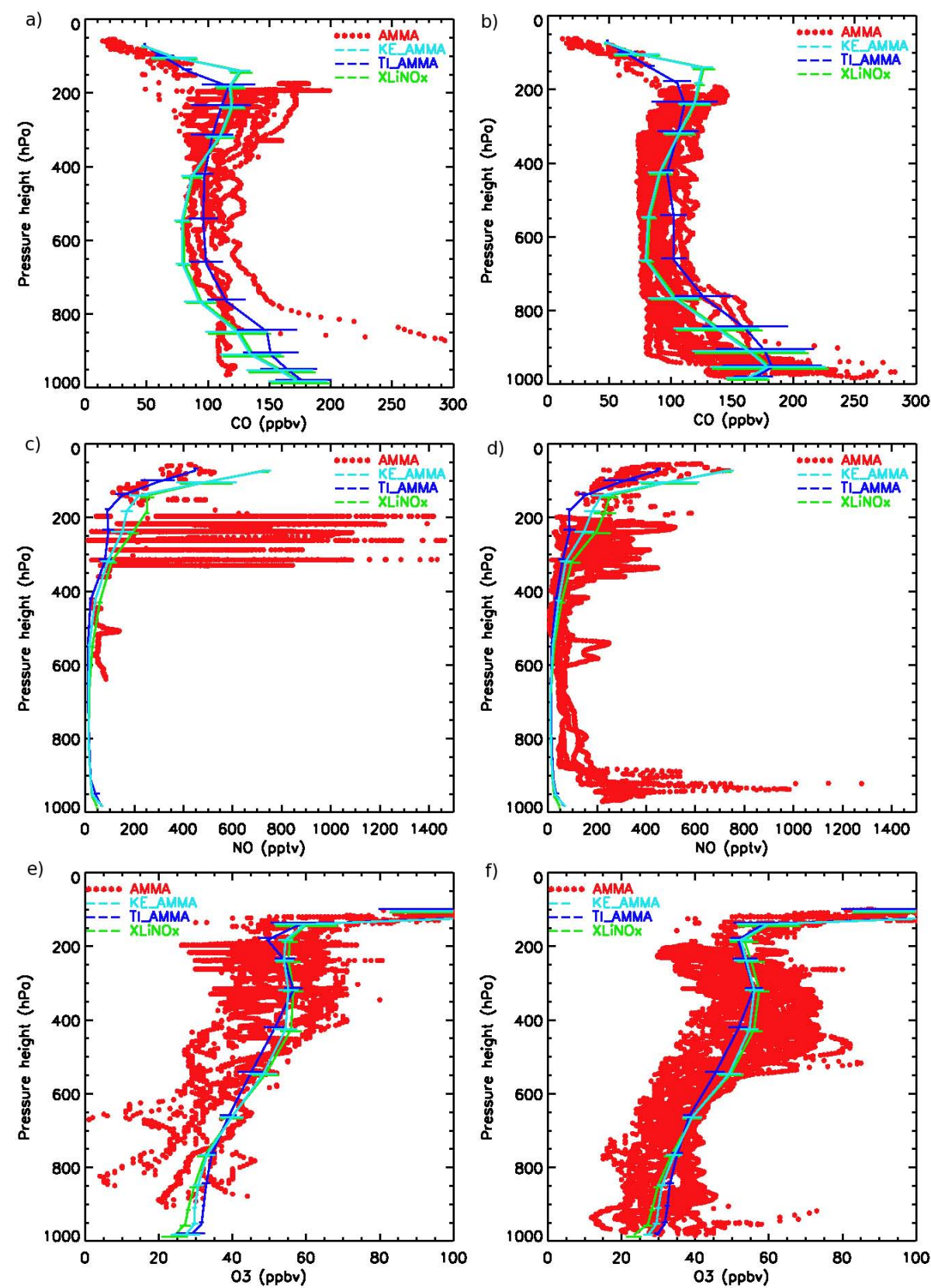

Fig. 3. Vertical $\mathrm{CO}(\mathbf{a}, \mathbf{b}), \mathrm{NO}(\mathbf{c}, \mathbf{d})$ and $\mathrm{O}_{3}(\mathbf{e}, \mathbf{f})$ profiles observed (red dots) during the AMMA campaign in August 2006 and simulated by KE_AMMA, TI_AMMA and XLiNOx. Observations and model results were divided into flights recently impacted by convection (left) and not impacted by recent deep convection (right). See text for details. The horizontal lines indicate the standard deviation in the model results.

CONV case. Furthermore, Huntrieser et al. (2011) showed higher CO, measured by the DLR aircraft, in outflow of MCS observed over southern forests than over the Sahel region.

The corresponding modelled $\mathrm{CO}$ profiles show that the model is able to capture the general shape of the $\mathrm{CO}$ profile. However, the model does not capture the enhanced variability in the CONV case seen in the data with mean profiles showing little difference between the CONV and NOCONV cases in the model. The model simulates convection every day over large parts of the region and, moreover, due to its low horizontal resolution, the model is not able to represent single convective events of the dimension of an MCS. The latitude of convection in the model is also less varied than was observed with convective uplift occurring, in general between 0 and $15^{\circ} \mathrm{N}$. It has also been shown more recently in a study using the dynamical part of the model that convection 
was occurring at midday rather than in the late afternoon seen in the observations (Grandpeix et al., 2010) and this may also help to explain the lack of variability in the CONV air masses.

Differences between the KE_AMMA and TI_AMMA simulations provide an indication of model sensitivity to different convection schemes. KE_AMMA is in better agreement with the observations in the UT and exhibits higher $\mathrm{CO}$ concentrations than TI_AMMA although TI_AMMA does show larger differences between the CONV and NOCONV cases. On the other hand, TI_AMMA shows higher CO values in the MT and LT. The Emanuel scheme transports more $\mathrm{CO}$ to the UT indicating deeper convection. However, this scheme leads to lower $\mathrm{CO}$ in the MT due to higher downdrafts of CO-poor air masses from the UT. Using inert COlike tracer simulations defined over West Africa, Williams et al. (2010a) showed higher tracer concentrations simulated in the UT in KE_AMMA than in models based on Tiedtke (e.g. TM4). In agreement with these results, Hourdin et al. (2010) demonstrated, using an idealized tracer defined over Africa in LMDz, that the tracer is injected higher by the Emanuel scheme than by Tiedtke. Furthermore, Barret et al. (2010) also showed that convective uplift into the UT is weaker in models based on the Tiedtke scheme.

The NO measurements (see Fig. 3c and d) show increased values (up to $1700 \mathrm{pptv}$ ) in the CONV profiles around 200 $350 \mathrm{hPa}$, while lowest values $(<800 \mathrm{pptv})$ are observed in the NOCONV case. Law et al. (2010) and Barret et al. (2010), in an analysis of M55 and DLR NO data, respectively, also showed clear signatures of NO increases in the UT in convectively influenced air masses attributed to production of NO from lightning and uplift of air masses impacted by $\mathrm{NO}_{\mathrm{x}}$ emissions from the LT. Stewart et al. (2008) and Delon et al. (2008) showed $\mathrm{NO}_{\mathrm{x}}$ concentrations exceeding $1 \mathrm{ppbv}$ measured by the BAe_146 in the LT around $15^{\circ} \mathrm{N}$. Such enhancements were attributed to $\mathrm{NO}_{\mathrm{x}}$ emissions from recently wetted soils. Uplift of such emissions may also contribute to the observed NO increases in the CONV case. Furthermore, Huntrieser et al. (2011) showed that $\mathrm{NO}_{\mathrm{x}}$ measured by the DLR in MCS outflow is a mixture of LiNOx and $\mathrm{NO}_{\mathrm{x}}$ transported upward from the LT. The modelled profiles underestimate the maximum of NO in the UT, particularly in the CONV case, although KE_AMMA has higher NO (150-200 pptv) compared to TI_AMMA (50-100 pptv). This difference between the two simulations is due to higher cloud top heights in the Emanuel scheme leading to higher lightning $\mathrm{NO}_{\mathrm{x}}$ production in KE_AMMA. It could also be due to more intense uplift of $\mathrm{NO}_{\mathrm{x}}$ emissions from the LT in this simulation. Barret et al. (2010) showed that all the global models participating in their study underestimated NO in the UT but LMDz_INCA and p_TOMCAT were most able to reproduce elevated NO concentrations. They also showed that the lightning $\mathrm{NO}_{\mathrm{x}}$ parameterization of Price and Rind (1992), based on convective cloud top height, used in most models including LMDz_INCA, tends to underestimate the flash activity over Central Africa in comparison to satellite lightning observations. Tost et al. (2007), using different convection schemes and lightning parameterizations in their model, also showed that when using certain convective schemes (e.g. Tiedtke, 1989), the parameterization of Price and Rind (1992) fails to reproduce the maximum of lightning activity that occurs over West Africa due to the low number of simulated convective events over this region. They concluded that large uncertainties still remain in the present-day parameterizations of lightning $\mathrm{NO}_{\mathrm{x}}$ production and even if a scaling factor is used in most parameterizations to reproduce the globally observed flash frequency, additional tuning of the parameters in convective and lightning schemes is needed. Based on analysis of LiNOx observations from different campaigns including AMMA, Huntrieser et al. (2011) provided different recommendations in order to improve current LiNOx schemes and discussed some of the parameters that are crucial for LiNOx estimates and should be considered in LiNOx parameterizations. Weak lightning $\mathrm{NO}_{\mathrm{x}}$ production over Africa in LMDz_INCA contributes therefore to the discrepancy with the observations. In order to improve model results, lightning $\mathrm{NO}_{\mathrm{x}}$ production was increased by $50 \%(+0.58 \mathrm{Tg} \mathrm{N})$ over Africa in sensitivity test XLiNOx (see Table 1). This simulation gives better results and shows up to 70 pptv NO increases in the UT in comparison to KE_AMMA. Whilst peak concentrations are still lower than mean observed values, these results demonstrate the considerable sensitivity of global model results to LiNOx treatments.

Concerning $\mathrm{O}_{3}$, there are only small differences between CONV and NOCONV compared to observed NO and to a lesser extent observed CO. This shows that constant persistent convection over this region is perturbing on a regional scale over West Africa making it difficult to distinguish CONV air masses in terms of their $\mathrm{O}_{3}$ concentrations. Also, as shown in the next section, $\mathrm{O}_{3}$ perturbations are higher downwind over the Atlantic Ocean than over West Africa. In both CONV and NOCONV cases, observed $\mathrm{O}_{3}$ profiles show increasing concentrations from the LT to around 300$400 \mathrm{hPa}$ where a maximum reaching $80 \mathrm{ppbv}$ was observed. These increases may be a result of either subsidence of $\mathrm{O}_{3}$ rich air masses from the UT to the lowest levels due to convective downdrafts, lightning production of $\mathrm{NO}_{\mathrm{x}}$ or uplift of $\mathrm{NO}_{\mathrm{x}}$ emissions from the LT leading to ozone production. Lower concentrations (30-60 ppbv) were measured in the region of convective outflow $(\sim 200 \mathrm{hPa})$ as a combined effect of deep convection uplift of $\mathrm{O}_{3}$-poor air masses from the forested regions near the Gulf of Guinea (Saunois et al., 2009; Huntrieser et al., 2011), latitudinal redistribution of $\mathrm{O}_{3}$ precursors by the UT branches of the Hadley cells (see next section) and import of air masses from the upwind regions such as Asia (Law et al., 2010). The model profiles agree reasonably well with the observed vertical distribution with only small differences between CONV and NOCONV as also observed. Results from KE_AMMA show higher $\mathrm{O}_{3}$ 

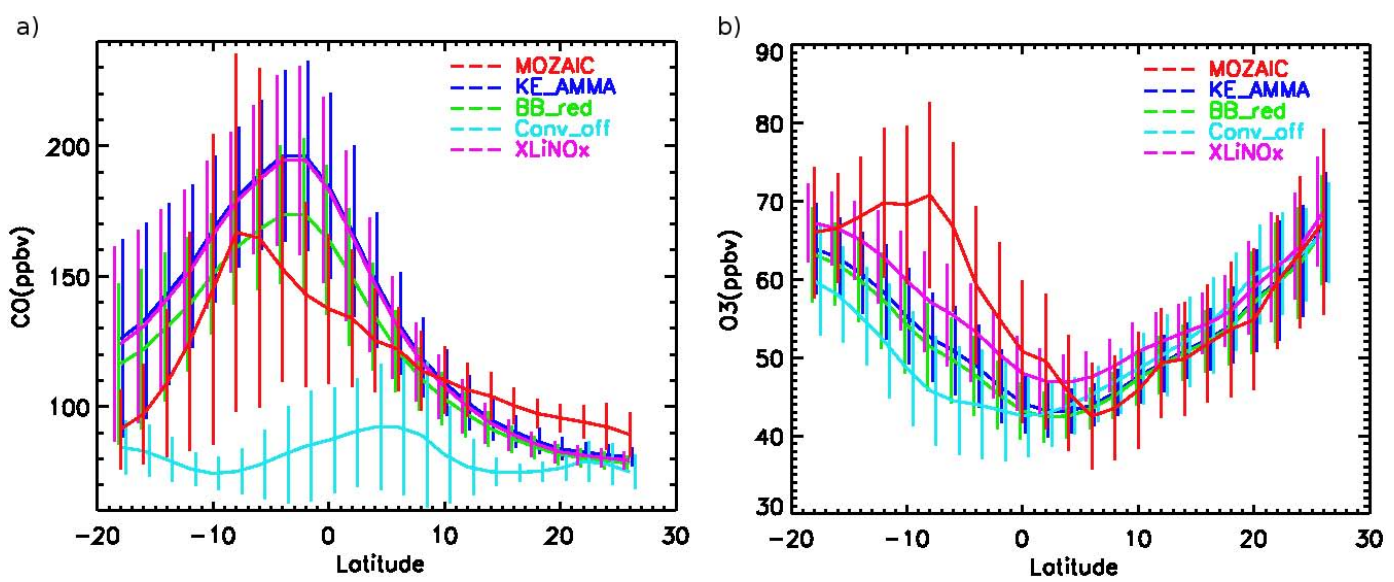

Fig. 4. $\mathrm{CO}$ (a) and $\mathrm{O}_{3}$ (b) concentrations (ppbv) observed as a function of latitude by MOZAIC aircraft in August 2006 and corresponding model output for the simulations KE_AMMA, BB_red, Conv_off and XLiNOx. See text for details. The vertical lines indicate the standard deviation in the model results.

concentrations $(\sim+5 \mathrm{ppbv})$ in the MT and UT, in particular in the CONV case, compared to TI_AMMA. This is due to higher LiNOx and higher downdrafts of $\mathrm{O}_{3}$-rich air masses from the UT in KE_AMMA. Increased lightning $\mathrm{NO}_{\mathrm{x}}$ production in XLiNOx leads to increased $\mathrm{O}_{3}(\sim 2 \mathrm{ppbv})$ in the MT and UT.

Overall, this comparison shows that LMDZ_INCA is able to reproduce broad features of the vertical profiles observed over West Africa during the summer monsoon although it is unable to capture the higher variability seen in $\mathrm{CO}$ data in air masses recently influenced by convection and the high NO concentrations observed in the mid and upper troposphere.

\subsection{Comparison with MOZAIC data}

A preliminary evaluation of LMDz_INCA against MOZAIC data was performed by Barret et al. (2010) where results from the KE_AMMA simulation were discussed. Barret et al. (2010) concluded that model performance is sensitive to biomass burning emission inventories and differences in convection and chemical schemes may explain differences between the models. This section further evaluates LMDz_INCA against MOZAIC data. Figure 4 shows $\mathrm{CO}$ and $\mathrm{O}_{3}$ measurements from MOZAIC over Africa at $250 \mathrm{hPa}$ during August 2006 compared to model output for the control simulation (KE_AMMA) and various sensitivity experiments (discussed below). Enhanced CO concentrations were observed south of the Equator with a maximum of $\sim 160 \mathrm{ppbv}$ observed at $8^{\circ} \mathrm{S}$. KE_AMMA captures the latitudinal gradient of $\mathrm{CO}$ but, in common with other models used in Barret et al. (2010), overestimates the measured maximum. The simulated maximum is higher by about $50 \mathrm{ppbv}$ and is reproduced further north around $3^{\circ} \mathrm{S}$ compared to the observations. As shown by Barret et al. (2010), deep convection and meridional transport within the upper branch of the
Hadley cell play a key role in the UT CO distribution and can explain the observed enhancements.

Switching off the convective transport in the Conv_off simulation leads to a significant decrease of $\mathrm{CO}$ in the UT confirming that the modelled CO distribution in the African UT is sensitive to convective uplift. BB emissions are an important source of $\mathrm{CO}$ in this region although they are not directly uplifted by convection over Central Africa but are transported in the LT northward to the convective region over Sudan/Chad before being uplifted into the UT and redistributed southwards over Central Africa by the large-scale Hadley circulation. The northward shift in simulated $\mathrm{CO}$ maximum in the UT compared to the observations appears to be due to the location of convection in the model. Analysis of meridional wind speed and vertical velocities from ECMWF and KE_AMMA in the UT (not shown) showed strongest ascending winds in the model over West Africa and north of $5^{\circ} \mathrm{S}$ over Central Africa. Moreover, Barret et al. (2010) showed that detrainment occurs over a larger meridional region in KE_AMMA simulation compared to other models. Comparisons with results from TI_AMMA are in better agreement with MOZAIC compared to KE_AMMA, due to weaker uplift into the UT, although simulated values are still higher compared to MOZAIC. The overestimation of UT CO in KE_AMMA could therefore be due to strong convective updrafts and detrainment in the Emanuel scheme leading to rapid uplift of $\mathrm{CO}$ from the $\mathrm{LT}$ and redistribution over a broad region. However, as shown by Barret et al. (2010), other global models based on the Tiedtke scheme (TM4 and p_TOMCAT) also tend to overestimate CO compared to MOZAIC. Another possibility is that biomass emissions are too high in the L3JRC dataset. Reducing the African $\mathrm{BB}$ emissions by $20 \%$ (i.e. $-31 \mathrm{Tg} \mathrm{CO}$ in BB_red) during the JJA period leads to better agreement with MOZAIC CO data. Therefore, the overestimation of UT CO could be due 
to an overestimation of $\mathrm{BB}$ emissions. Convective uplift may also be too strong over Central Africa since it has only been possible to validate vertical profiles further north over West Africa where convective uplift of $\mathrm{CO}$ seems to be reasonably well simulated.

Low $\mathrm{O}_{3}$ concentrations (less than $50 \mathrm{ppbv}$ ) were observed by MOZAIC over the convective region between 0 and $15^{\circ} \mathrm{N}$. The highest values occur north and south of this region as a result of $\mathrm{O}_{3}$ formation in the upper level branches of the Hadley circulation as already reported in previous studies (Sauvage et al., 2007c; Barret et al., 2010). The latitudinal distribution of $\mathrm{O}_{3}$ observed by MOZAIC is fairly well reproduced by the model simulations although the shape of $\mathrm{O}_{3}$ transect south of $5^{\circ} \mathrm{N}$ is not reproduced correctly. However, KE_AMMA underestimates $\mathrm{O}_{3}$ by up to $20 \mathrm{ppbv}$ south of the Equator at around $10^{\circ} \mathrm{S}$. Barret et al. (2010) showed that other models (except MOCAGE) also fail to capture the observed maximum and that KE_AMMA also underestimates $\mathrm{O}_{3}$ relative to MLS observations at around $10^{\circ} \mathrm{S}$. As noted in the comparisons with MOZAIC CO, these discrepancies may be due to a combination of factors linked to convective uplift and emission sources. Modelled $\mathrm{O}_{3}$ in the UT over Central Africa is rather insensitive to surface BB emissions with results from the $\mathrm{BB}$ red run showing only small changes in $\mathrm{UT} \mathrm{O}_{3}$ relative to KE_AMMA (1 ppbv decreases south of the Equator). Results from emission sensitivity runs (see Sect. 5.4 and Fig. 9) confirm this low model sensitivity to Central African BB emissions, despite significant convective uplift of these emissions. UT $\mathrm{O}_{3}$ is also sensitive to available $\mathrm{NO}_{\mathrm{x}}$ and so, it is possible that there is insufficient modelled photochemical production in $\mathrm{BB}$ air masses or too much production of $\mathrm{HNO}_{3}$, which is then washed out during convection leading to too little $\mathrm{O}_{3}$ in the UT. Modelled $\mathrm{UT} \mathrm{O}_{3}$ is also rather insensitive to other surface emissions (biogenic VOCs, soil $\mathrm{NO}_{\mathrm{x}}$ and anthropogenic sources $<1$ ppbv $\mathrm{O}_{3}$ changes). On the other hand, model results are most sensitive to lightning $\mathrm{NO}_{\mathrm{x}}$ emissions (see Sect. 5) which, following the analysis presented in the previous section, are underestimated. This direct injection of $\mathrm{NO}_{\mathrm{x}}$ leading to photochemical $\mathrm{O}_{3}$ production downwind is a significant source of $\mathrm{O}_{3}$ in the UT. Increasing lightning $\mathrm{NO}_{\mathrm{x}}$ production by $50 \%$ over Africa in the XLiNOx simulation during JJA leads to higher $\mathrm{O}_{3}$ concentrations (up to $6 \mathrm{ppbv}$ ) south of the Equator. The influence of lightning $\mathrm{NO}_{\mathrm{x}}$, which is mainly produced over West Africa during the monsoon season, extends up to Central Africa due to southward redistribution of such emissions in the UT by the Hadley circulation (see Sect. 5.1 and Fig. 6). This is also confirmed by the Conv_off experiment, where both lightning $\mathrm{NO}_{\mathrm{x}}$ emissions and convection were switched off. In this run, the underestimation of UT $\mathrm{O}_{3}$ in LMDz_INCA is more pronounced compared to KE_AMMA.

Thus, while overestimation of convective uplift and BB emissions may explain the overestimation of MOZAIC CO data, a combination of weak lightning $\mathrm{NO}_{\mathrm{x}}$ emissions and weak photochemical production in uplifted (BB) air masses may explain the underestimation of $\mathrm{MOZAIC} \mathrm{O}_{3}$. Enhanced washout of $\mathrm{NO}_{\mathrm{x}}$ reservoir species, linked to strong convection, may also impact the amount of $\mathrm{NO}_{\mathrm{x}}$ available for $\mathrm{O}_{3}$ production over downwind regions over Central Africa in the model.

\subsection{Comparison with satellite data}

To evaluate the spatial distribution of $\mathrm{O}_{3}$ precursors, Figure 5 shows average total columns of $\mathrm{CO}$ and tropospheric columns of $\mathrm{NO}_{2}$ observed during August 2006 compared to model results from the KE_AMMA and BB_red simulations. Strong CO enhancements are observed over the BB region in Central Africa and over the outflow regions in the Atlantic Ocean and Gulf of Guinea. Whilst spatial distribution is reasonably well reproduced, total $\mathrm{CO}$ columns are overestimated over Central Africa and downwind as far as the Brazilian coast in KE_AMMA $(+50 \%)$. CO columns in BB_red show lower values $(\sim-15 \%)$ over Central Africa compared to KE_AMMA. Therefore, the discrepancy in KE_AMMA appears to be due to an overestimation of $\mathrm{CO}$ from African $\mathrm{BB}$ emissions in the L3JRC inventory as already discussed in the previous section. In another model simulation based on the GFEDv2 inventory (not shown) total $\mathrm{CO}$ was too low confirming that Central African BB emissions are underestimated in this inventory. Therefore, the $\mathrm{CO} \mathrm{BB}$ emissions over Africa during the monsoon season probably lie between the GFEDv2 and L3JRC inventories, as already suggested by Barret et al. (2010). Another possible reason for the discrepancy in KE_AMMA is the uncertainty in MOPITT retrievals which are less sensitive to $\mathrm{CO}$ concentrations at the lowest altitudes (Emmons et al., 2007, 2009). Emmons et al. (2009) found that $\mathrm{CO}$ columns larger than $4 \times 10^{18} \mathrm{~mol} \mathrm{~cm}^{-2}$ are not considered in the MOPITT V3 product used in this study. This may lead therefore to a negative bias in MOPITT measurements over regions such as Central Africa. The modelled $\mathrm{NO}_{2}$ tropospheric columns agree reasonably well with SCIAMACHY measurements although the simulated maximum over Central Africa is overestimated. This discrepancy may be attributed to an overestimation of BB emissions in L3JRC or to the uncertainties in satellite measurements of $\mathrm{NO}_{2}$ (van Noije et al., 2006). The model captures the enhanced $\mathrm{NO}_{2}$ observed over the anthropogenic emissions sources of South Africa but underestimates the observed maximum. Westward export from Central Africa is more northerly in both $\mathrm{NO}_{2}$ and $\mathrm{CO}$ measurements than in the model. This could explain therefore the low $\mathrm{NO}_{2}$ values simulated over the Gulf of Guinea.

Another possible explanation for the discrepancy between KE_AMMA and satellite column data is the fact that both MOPITT and SCIAMACHY retrievals are biased to clear sky scenes. Indeed, this reduces the number of observations available for comparison and thereby increases the uncertainty in the observations. Furthermore, the satellite data may underestimate $\mathrm{CO}$ and $\mathrm{NO}_{2}$ from fires if there is a lot of 

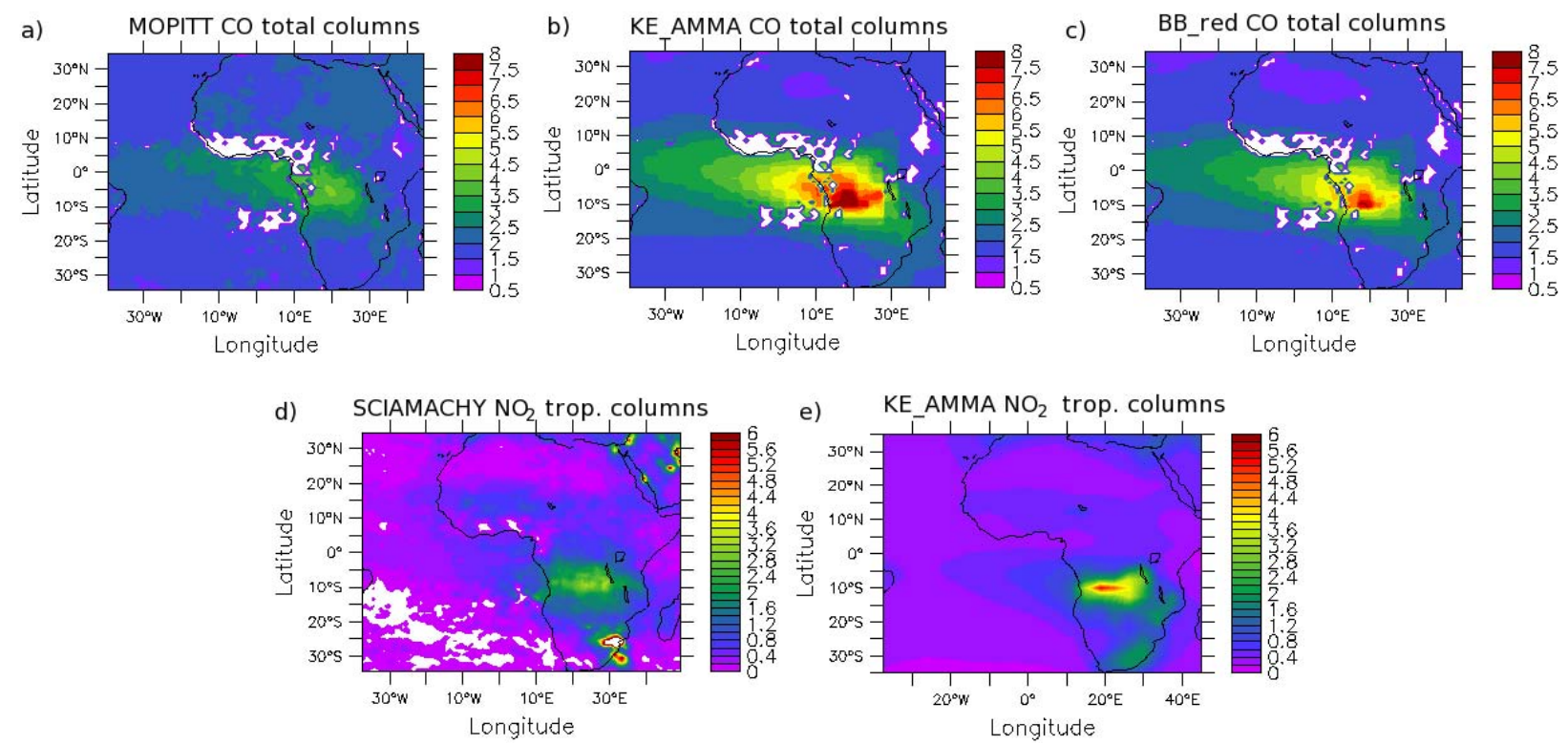

Fig. 5. Total columns of $\mathrm{CO}\left(10^{18}\right.$ molec $\left.\mathrm{cm}^{-2}\right)$ and tropospheric columns of $\mathrm{NO}_{2}\left(10^{15}\right.$ molec $\left.\mathrm{cm}^{-2}\right)$ observed by MOPITT (a) and SCIAMACHY (d) respectively and corresponding KE_AMMA and BB_red simulations (b, c, e) averaged for August 2006.
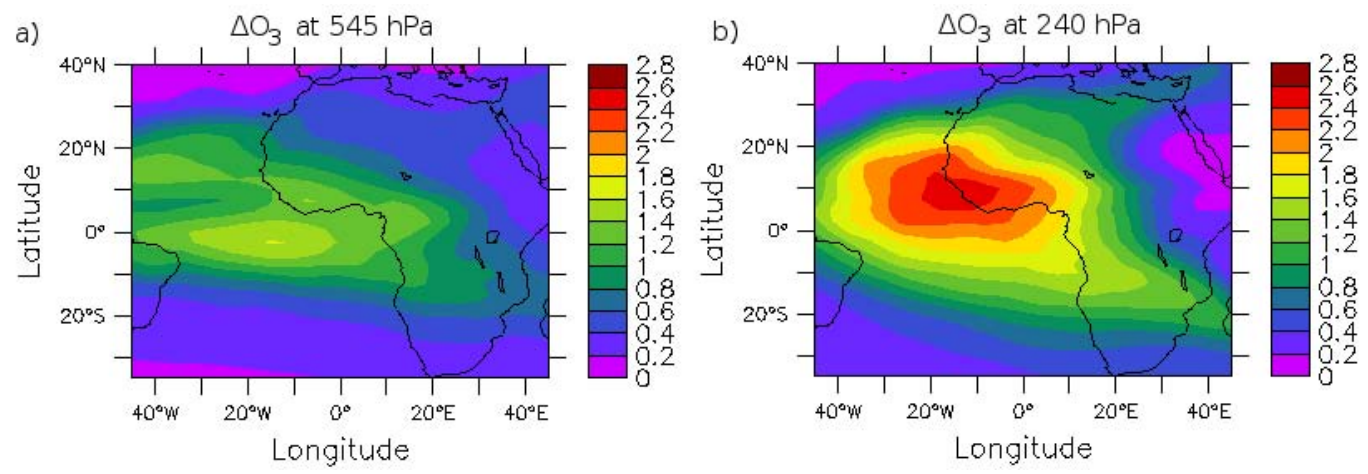

Fig. 6. KE_AMMA - LiNOx_red $\mathrm{O}_{3}$ differences $\left(\Delta \mathrm{O}_{3}\right)$ in ppbv at $545 \mathrm{hPa}($ a) and $240 \mathrm{hPa}(\mathbf{b})$.

aerosol or clouds obscuring the fire regions. However, this is difficult to account for since there is no readily available information on the presence of aerosols, their distribution and type. Furthermore, the BB emissions occur over Central Africa far from the cloudy convective regions associated with the summer monsoon. However, some data may be missed if aerosol or smoke is mistaken as cloud but this depends on fire type and phase during the satellite overpass.

In summary, this comparison against observations shows that the model performs reasonably well over West Africa in terms of ability to model the spatial and vertical distribution of $\mathrm{O}_{3}$ and its precursors. However, model results are improved in runs with higher lightning $\mathrm{NO}_{\mathrm{x}}$ and lower $\mathrm{BB}$ emissions. This point is taken into account in the following analysis of the emissions contributing to $\mathrm{O}_{3}$ distributions over West Africa and downwind.

\section{Influence of African and Asian emissions}

In this section, we investigate the contribution of African emissions to $\mathrm{O}_{3}$ distributions over Equatorial Africa during the monsoon season. The impact of downwind transport of different emissions on $\mathrm{O}_{3}$ is also discussed. Model runs starting in May 2006 were performed with a small perturbation $(-20 \%)$ to the following emission categories over Africa (see Fig. 1): lightning $\mathrm{NO}_{\mathrm{x}}$, soil $\mathrm{NO}_{\mathrm{x}}$, biogenic VOCs, biomass burning, or anthropogenic emissions (see Table 1). In the case of LiNOx, we also comment on the results obtained from the XLiNOx run when LiNOx emissions were increased by $50 \%$ in the model since these results agree better with the observations. In the following sections, the difference $\left(\Delta \mathrm{O}_{3}\right)$ in the simulated $\mathrm{O}_{3}$ concentrations during JJA between the control experiment and sensitivity tests when various emissions were reduced are examined. This 
analysis allows identification of regions where $\mathrm{O}_{3}$ is influenced by different emissions. In order to quantify the sensitivity of reducing different emissions on $\mathrm{O}_{3}$, the calculated $\Delta \mathrm{O}_{3}$ were also normalized by dividing by the unit change in $\mathrm{NO}_{\mathrm{x}}(\Delta \mathrm{Tg} \mathrm{N})$ and carbon $(\Delta \mathrm{Tg} \mathrm{C})$ emissions (see Sect. 5.7).

\subsection{Influence of lightning $\mathrm{NO}_{\mathrm{x}}$}

Figure 6 depicts the impact of reducing LiNOx by $20 \%$ over Africa (LiNOx_red) on $\mathrm{O}_{3}$ concentrations. The main influence on $\mathrm{O}_{3}$ can be seen in the MT and UT where $\mathrm{O}_{3}$ concentrations change by 1 to $2 \mathrm{ppbv}$ and 2 to $3 \mathrm{ppbv}$, respectively. $\mathrm{O}_{3}$ changes occur principally over the convective regions of West Africa and downwind over the tropical Atlantic and Central Africa. Results from other models, discussed in Barret et al. (2010), showed similar regions impacted by LiNOx during August 2006. In an analysis of modelled total $\mathrm{O}_{3}$ columns, Sauvage et al. (2007b) showed a large influence of LiNOx on $\mathrm{O}_{3}$ over the Central Atlantic during JJA 2000 in their model. Differences exist however in the maximum influence which occurred between $10^{\circ} \mathrm{S}$ and $10^{\circ} \mathrm{N}$ in Sauvage et al. (2007b), but is found north of $10^{\circ} \mathrm{N}$ in LMDz_INCA. This was also the case in p-TOMCAT, as shown in Barret et al. (2010), although other models participating in that study showed lower $\mathrm{O}_{3}$ enhancements over this region and maximum changes between 0 and $10^{\circ} \mathrm{N}$ (e.g. in TM4). This large spatial influence of LiNOx on $\mathrm{O}_{3}$ can be explained by the advection of $\mathrm{NO}_{\mathrm{x}}$-rich air masses from Africa downwind to other regions by the AEJ in the MT, and the TEJ in the UT followed by photochemical $\mathrm{O}_{3}$ production. The large-scale Hadley circulation also redistributes UT air masses north and south (as discussed in Sect. 4.2). Analysis of the XLiNOx results showed that increasing by $50 \%$ the LiNOx in the model leads to $\mathrm{O}_{3}$ changes up to 6 ppbv in the UT compared to KE_AMMA. Excluding all the LiNOx emissions over Africa in LMDz_INCA leads to $\mathrm{O}_{3}$ changes of up to $20 \mathrm{ppbv}$ in the UT (as discussed in Barret et al., 2010). Maximum $\mathrm{O}_{3}$ changes in other models (MOCAGE and TM4) were lower (10 ppbv and 15 ppbv respectively) indicating a higher influence of $\mathrm{LiNOx}$ on $\mathrm{O}_{3}$ in LMDz_INCA. Overall, these results show that $\mathrm{O}_{3}$ changes due to $100 \%$ LiNOx perturbation are higher than 2 times the changes due to a $50 \%$ perturbation (XLiNOx) and even higher than 5 times the changes due to a $20 \%$ perturbation (LiNOx_red). This suggests that the response of $\mathrm{O}_{3}$ changes to LiNOx perturbations in LMDz_INCA shows a strong nonlinearity.

\subsection{Influence of soil $\mathrm{NO}_{\mathrm{x}}$}

The following section shows results from the SNOx_red run (Fig. 7) where soil $\mathrm{NO}_{\mathrm{x}}$ emissions were reduced by $20 \%$ over Africa. In this case, significant $\mathrm{O}_{3}$ changes occur in the LT over the high emissions region of the Sahel (up to 1.5 ppbv). $\mathrm{O}_{3}$ sensitivity to soil $\mathrm{NO}_{\mathrm{x}}$ emissions is also found in the UT where changes occur over West Africa and down- wind over the Gulf of Guinea (more than $1 \mathrm{ppbv}$ ) as well as further downwind over the Atlantic Ocean and reaching into North Africa. The significant influence of soil $\mathrm{NO}_{\mathrm{x}}$ emissions on $\mathrm{O}_{3}$ in the UT is due both to upward transport of $\mathrm{NO}_{\mathrm{x}}$-rich air masses followed by photochemical production as well as photochemical production from soil $\mathrm{NO}_{\mathrm{x}}$ in the LT followed by deep convection uplift. A lower impact on $\mathrm{O}_{3}$ (less than $1 \mathrm{ppbv}$ ) occurs north of $16.5^{\circ} \mathrm{N}$, where precipitation is less abundant and soil emissions are lower, and also over the Guinean coast where the vegetation suppresses soil $\mathrm{NO}_{\mathrm{x}}$ emissions. Lower $\mathrm{O}_{3}$ changes (less than 1 ppbv) are also found in the MT over the Gulf of Guinea and the Atlantic Ocean in air masses advected from the continent by the AEJ. According to these results, we estimate that soil $\mathrm{NO}_{\mathrm{x}}$ emissions in LMDz_INCA have a maximum contribution of 6 to 8 ppbv to surface $\mathrm{O}_{3}$ over the Sahel region, if we assume that $\mathrm{O}_{3}$ changes due to excluding all the soil $\mathrm{NO}_{\mathrm{x}}$ emissions can be considered equal to 5 times the $\mathrm{O}_{3}$ changes calculated from the $20 \%$ test. Saunois et al. (2009) calculated a maximum contribution in the same range $(7 \mathrm{ppbv})$ to surface $\mathrm{O}_{3}$ from soil $\mathrm{NO}_{\mathrm{x}}$ emissions near $16^{\circ} \mathrm{N}$ in their latitude-altitude model run over West Africa. Since their model represented a longitudinal average over the region, they did not consider transport of $\mathrm{O}_{3}$ precursors downwind and subsequent $\mathrm{O}_{3}$ production which we find to be important.

\subsection{Influence of biogenic VOC emissions}

Figure 8 shows results from the BIO_red simulation in which biogenic VOC emissions were reduced by $20 \%$ over Africa. It can be seen that the highest impact on $\mathrm{O}_{3}$ occurs in the UT between $300 \mathrm{hPa}$ and $100 \mathrm{hPa}$ where changes of 2 to $3 \mathrm{ppbv}$ are simulated over West Africa and the Atlantic Ocean. Aghedo et al. (2007) also reported a large contribution from African biogenic VOC emissions to $\mathrm{O}_{3}$ above $300 \mathrm{hPa}$ in the ECHAM5-MOZ model. The impact of the BIO_red run on $\mathrm{UT} \mathrm{O}_{3}$ also extends into Central and Northern Africa (up to 1 ppbv $\mathrm{O}_{3}$ changes) due to redistribution of air masses within the UT branches of the Hadley circulation. Running the model with convection switched off (Conv_off run) leads to an important decrease in isoprene concentrations above $400 \mathrm{hPa}$ suggesting that biogenics can be transported into the UT. This is supported by Bechara et al. (2010) who found elevated VOC concentrations (up to 3 times higher) in the UT during convective events in their analysis of aircraft data. This suggests that convective uplift of VOC emissions into the UT provides an important source of peroxy radicals which, in the presence of $\mathrm{NO}_{\mathrm{x}}$, either from lightning or uplifted from soil emission regions, lead to enhanced photochemical $\mathrm{O}_{3}$ production. Lower but significant $\mathrm{O}_{3}$ changes ( 1 to 2 ppbv) are also found over the Sahel and Gulf of Guinea in the LT and MT. We estimate that switching off biogenic VOC emissions in LMDz_INCA would lead to maximum $\mathrm{O}_{3}$ changes of nearly $8 \mathrm{ppbv}$ in the LT and MT and $13 \mathrm{ppbv}$ in the UT during the JJA season. Saunois et 

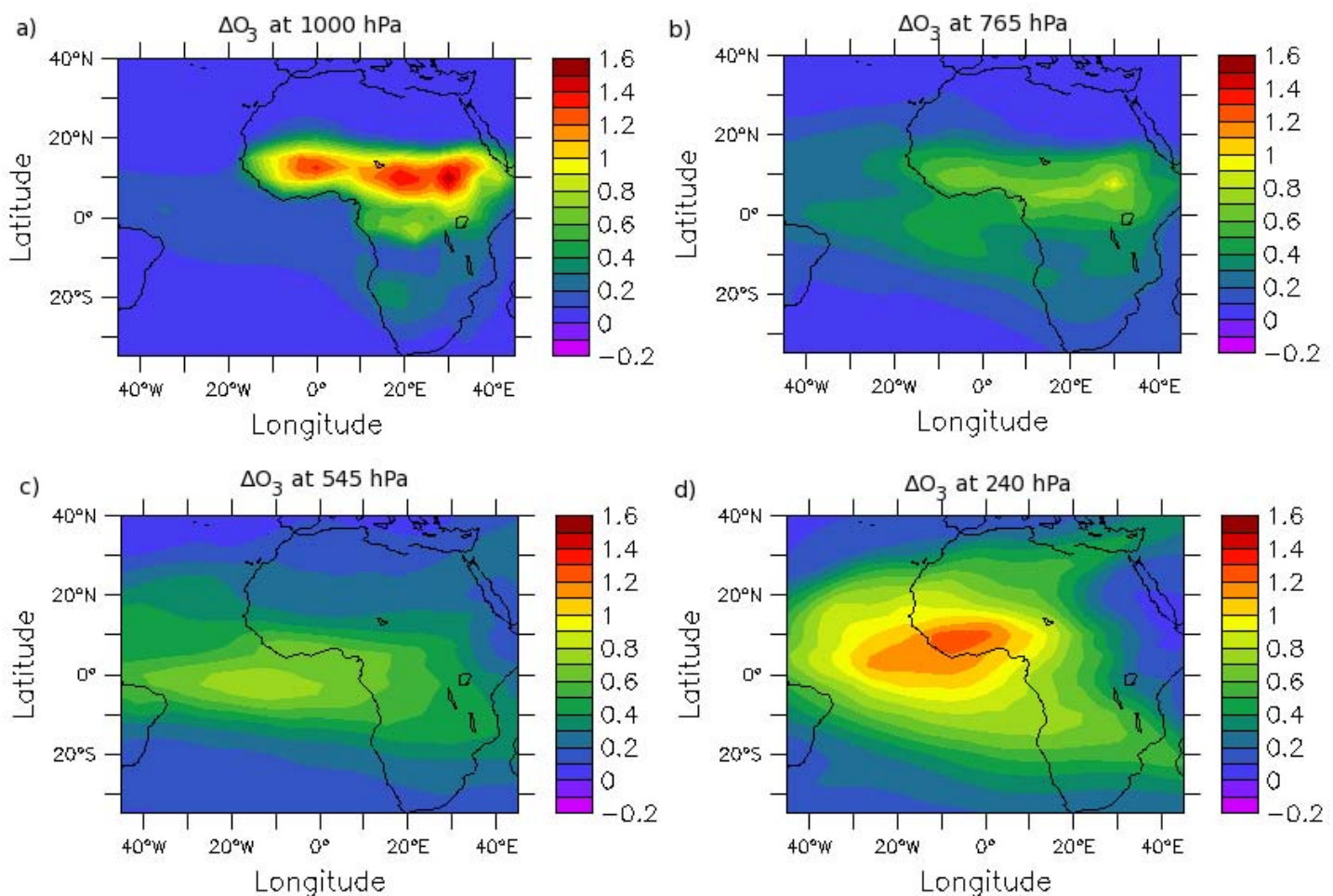

Fig. 7. KE_AMMA-SNOx_red $\mathrm{O}_{3}$ differences $\left(\Delta \mathrm{O}_{3}\right)$ in ppbv at $1000 \mathrm{hPa}(\mathbf{a}), 765 \mathrm{hPa}(\mathbf{b}), 545 \mathrm{hPa}(\mathbf{c})$ and $240 \mathrm{hPa}(\mathbf{d})$.
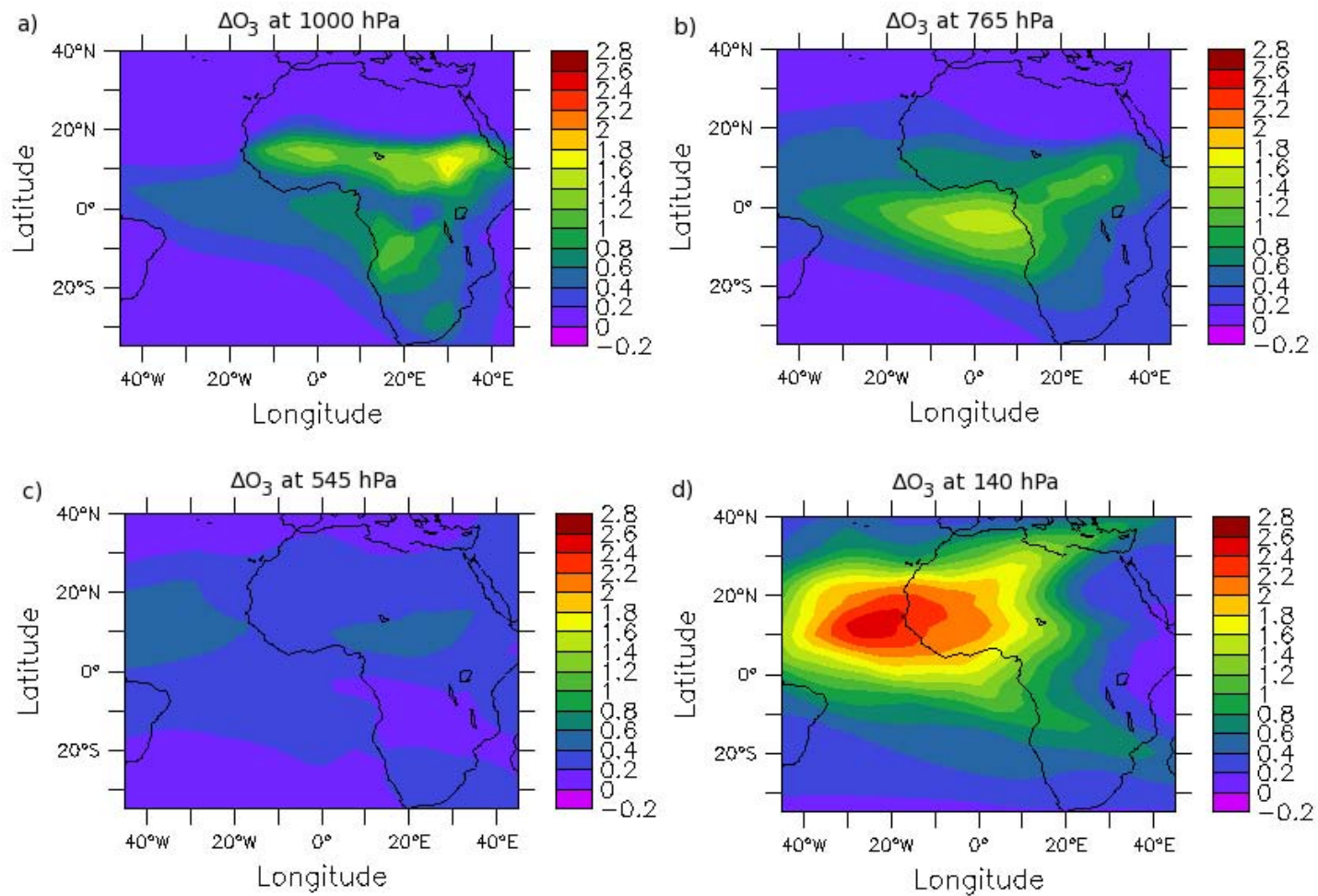

Fig. 8. KE_AMMA - BIO_red $\mathrm{O}_{3}$ differences $\left(\Delta \mathrm{O}_{3}\right)$ in ppbv at $1000 \mathrm{hPa}(\mathbf{a}), 765 \mathrm{hPa}(\mathbf{b}), 545 \mathrm{hPa}(\mathbf{c})$ and $140 \mathrm{hPa}(\mathbf{d})$. 
al. (2009) calculated maximum $\mathrm{O}_{3}$ changes of 5 ppbv in the LT around $16^{\circ} \mathrm{N}$ and found no significant impact between $6^{\circ} \mathrm{N}$ and $13^{\circ} \mathrm{N}$ while in $\mathrm{LMDz}_{-} \mathrm{INCA} \mathrm{O}_{3}$ changes can reach 4 ppbv over the same region. This difference may be due to differences in $\mathrm{VOC}$ and $\mathrm{NO}_{\mathrm{x}}$ emissions, and to the fact that only isoprene and terpenes emissions were switched off in Saunois et al. (2009), while other VOCs (e.g. methanol) were also switched off in BIO_red. Aghedo et al. (2007) calculated $\mathrm{O}_{3}$ changes of 10 to $30 \mathrm{ppbv}$ in the LT when both biogenic VOCs and soil $\mathrm{NO}_{\mathrm{x}}$ emissions were excluded from their model. Since ozone changes of up to $8 \mathrm{ppbv}$ were found in the BIO_red and SNOx_red tests in LMDz_INCA, we can expect to see $\mathrm{O}_{3}$ changes of more than $8 \mathrm{ppbv}$ if both VOC and soil $\mathrm{NO}_{\mathrm{x}}$ emissions are switched off in the model.

\subsection{Influence of biomass burning emissions}

Results from the $-20 \% \mathrm{BB}$ emissions test are shown in Fig. 9. The largest influence on $\mathrm{O}_{3}$ occurs in the LT and MT in the model. Changes up to $3 \mathrm{ppbv}$ and $11 \mathrm{ppbv}$ are simulated over the Gulf of Guinea and over the regions of intense BB activity in Central Africa, respectively. Changes up to 4 ppbv are also simulated north of the $\mathrm{BB}$ emissions region as a result of northward transport of these emissions in the LT. Westward advection of BB plumes in the MT extends the impact of $\mathrm{BB}$ emissions as far as $20^{\circ} \mathrm{W}$ where $\mathrm{O}_{3}$ changes of 2 to 8 ppbv are estimated over the Atlantic. The lowest impact occurs in the UT where maximum $\mathrm{O}_{3}$ changes of 2 ppbv and $1 \mathrm{ppbv}$ are found over Central Africa and the Atlantic Ocean, respectively. Williams et al. (2010b), using various TM4 simulations, also showed that the most significant effect of Central African BB emissions occurs in the LT and MT. However, as already discussed in section 4.1, the evaluation of the LMDz_INCA against AMMA aircraft data suggested that the model fails to reproduce the enhancements in $\mathrm{O}_{3}$ observed over the Gulf of Guinea due to weak northward transport of BB emissions in the MT. Furthermore, comparison with MOZAIC data (see Sect. 4.2) showed that the model tends to underestimate $\mathrm{O}_{3}$ in the UT south of the Equator. Therefore, the contribution of $\mathrm{BB}$ emissions to $\mathrm{O}_{3}$ in the UT and over the Gulf of Guinea could be higher than estimated from these model calculations.

Turning off all African BB emissions in LMDz_INCA during JJA leads to $\mathrm{O}_{3}$ changes in the LT of up to 55 ppbv over Central Africa and up to 15 ppbv over the Gulf of Guinea. Similar changes were calculated by Aghedo et al. (2007) over the same regions (up to $60 \mathrm{ppbv}$ and $15 \mathrm{ppbv}$, respectively) when BB emissions were excluded from their model. However, they showed an influence on $\mathrm{O}_{3}$ extending far inland reaching $15^{\circ} \mathrm{N}$ especially over East Africa where they calculated 5 to 10 ppbv $\mathrm{O}_{3}$ changes. In LMDz_INCA (see Fig. 9) this influence extends only to $6^{\circ} \mathrm{N}$. This difference is probably due to differences in meteorological forcing (Aghedo et al. (2007) used ECMWF data for the 1997-2001 period while we used the 2006 winds) leading to differences in transport pathways of BB emissions. As shown by Mari et al. (2008), the export of $\mathrm{BB}$ plumes out of Central Africa can change markedly on daily basis and is controlled by the variability of the southerly branch of the AEJ. In the MT and UT we can expect to see $\mathrm{O}_{3}$ changes of 20 to $40 \mathrm{ppbv}$ and up to $4 \mathrm{ppbv}$, respectively, over the Atlantic Ocean. Williams et al. (2010b) calculated similar $\mathrm{O}_{3}$ changes (up to $30 \mathrm{ppbv}$ in MT and up to 5 ppbv in UT) over the Atlantic Ocean (between $3^{\circ} \mathrm{W}-$ $6^{\circ} \mathrm{E}$ ) during JJA 2006 when south African BB emissions were switched off in TM4, although they used the GFEDv2 $\mathrm{BB}$ inventory which has lower $\mathrm{CO}$ and $\mathrm{NO}_{\mathrm{x}}$ emissions compared to the L3JRC inventory used in our study. This could be due to differences in the photochemical $\mathrm{O}_{3}$ production efficiency which appears to be higher in their model compared to LMDz_INCA (Williams et al., 2010a). The insufficient photochemical $\mathrm{O}_{3}$ production in $\mathrm{BB}$ air masses in LMDz_INCA is probably linked to a low sensitivity of modelled $\mathrm{O}_{3}$ to available $\mathrm{CO}$, as discussed in Sect. 4.2. Indeed, despite higher $\mathrm{CO}$ emissions in L3JRC, which seem to be overestimated, modelled $\mathrm{O}_{3}$ is more sensitive to available $\mathrm{NO}_{\mathrm{x}}$. Therefore, the contribution of $\mathrm{BB}$ emissions to $\mathrm{O}_{3}$ in the MT (and the UT) could be higher than estimated using the LMDz_INCA model. Overall, our results show that BB emissions over Central Africa are a major source of ozone over Equatorial Africa during the summer monsoon.

\subsection{Influence of anthropogenic emissions}

Figure 10 shows results from the ANTH_red where African anthropogenic emissions were reduced by $20 \%$. They make only a small contribution to $\mathrm{O}_{3}$ over Equatorial Africa in comparison to other emissions. This agrees with Williams et al. (2010b) who found only a few percent change in $\mathrm{O}_{3}$ occurring in the LT when anthropogenic emissions were increased by $8.4 \%$ over Africa in TM4. The $\mathrm{O}_{3}$ changes in the ANTH_red run are mostly less than $1 \mathrm{ppbv}$ and occur in the LT over the anthropogenic emission regions near the Guinean coast and Central Southern Africa. Changes of less than 1 ppbv also occur at and above $240 \mathrm{hPa}$ extending into the Atlantic Ocean and Gulf of Guinea. In another simulation where only $\mathrm{CO}$ and $\mathrm{NO}_{\mathrm{x}}$ anthropogenic emissions were reduced by $20 \%$ and not VOCs (not shown), lower $\mathrm{O}_{3}$ changes (35\% less than changes in ANTH_red) were simulated above $240 \mathrm{hPa}$. This suggests that convective uplift of anthropogenic VOCs may make a small contribution to $\mathrm{O}_{3}$ formation in the upper troposphere - lower stratosphere (UTLS). According to these results, we estimate that switching off the anthropogenic emissions in LMDz_INCA leads to $\mathrm{O}_{3}$ changes of up to 3 ppbv in the LT over Nigeria and South Africa and 3 to 6 ppbv over Angola and the Central African Republic. These results are similar to the changes calculated by Saunois et al. (2009) over West Africa. Aghedo et al. (2007) calculated higher changes (up to $6 \mathrm{ppbv}$ ) over Nigeria but lower changes (1 to 2 ppbv) over Central Africa. This difference is probably due to differences in anthropogenic emissions (based on the EDGARv2 inventory in 

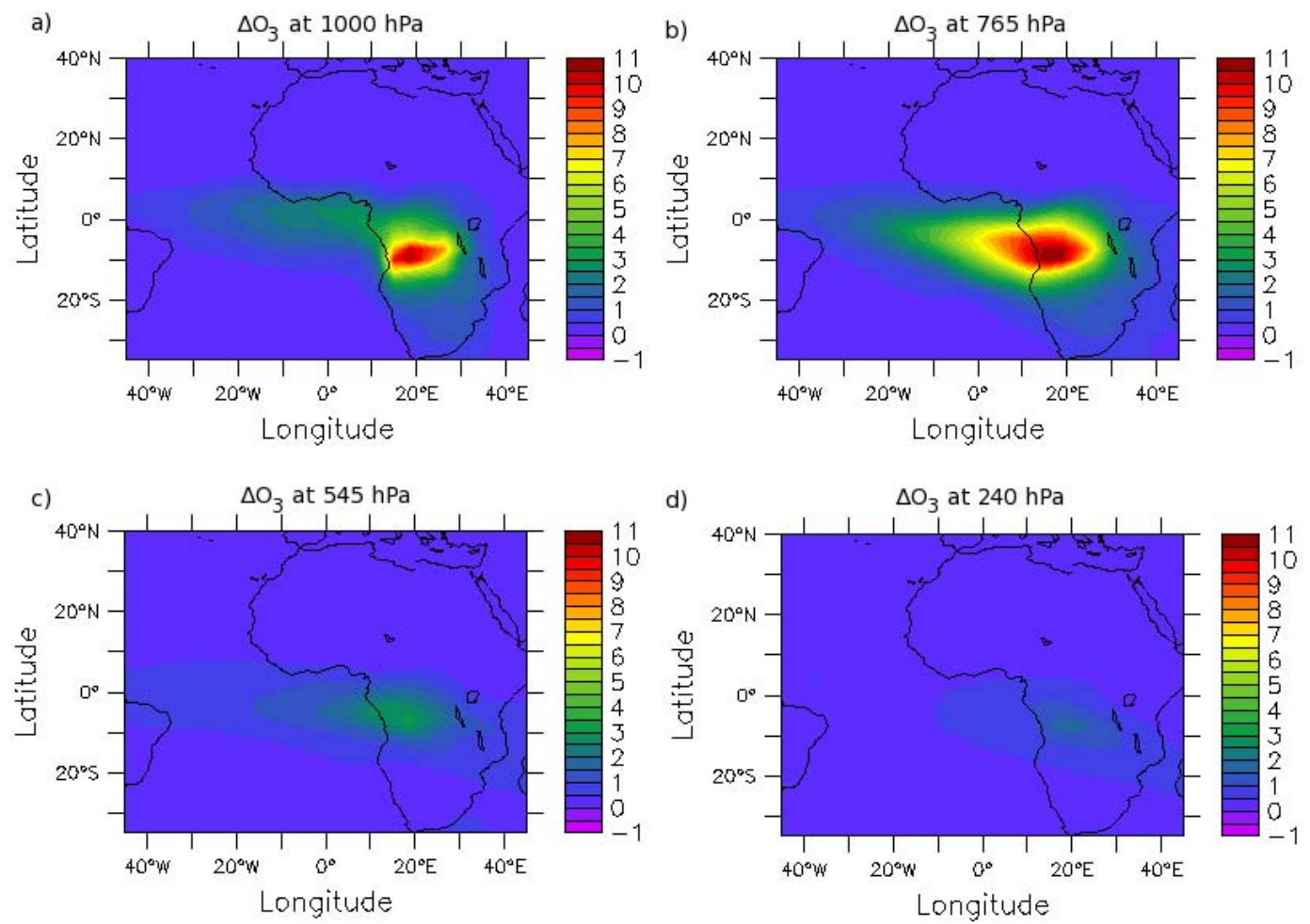

Fig. 9. KE_AMMA - BB_red $\mathrm{O}_{3}$ differences $\left(\Delta \mathrm{O}_{3}\right)$ in ppbv at $1000 \mathrm{hPa}(\mathbf{a}), 765 \mathrm{hPa}(\mathbf{b}), 545 \mathrm{hPa}$ (c) and $240 \mathrm{hPa}(\mathbf{d})$.
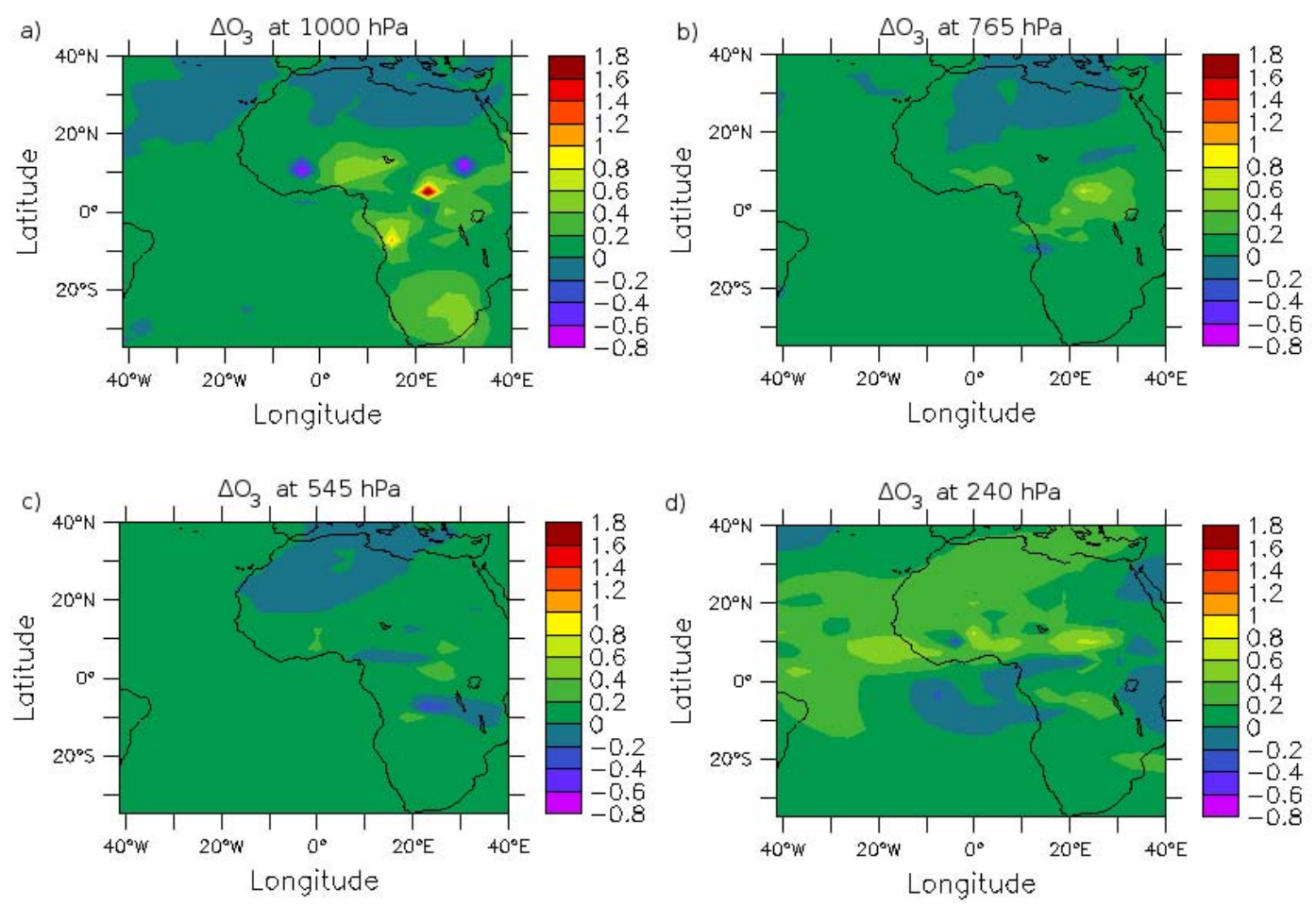

Fig. 10. $\mathrm{KE} \_\mathrm{AMMA}$ - $\mathrm{ANTH} \_$red $\mathrm{O}_{3}$ differences $\left(\Delta \mathrm{O}_{3}\right)$ in ppbv at $1000 \mathrm{hPa}(\mathbf{a}), 765 \mathrm{hPa}(\mathbf{b}), 545 \mathrm{hPa}(\mathbf{c})$ and $240 \mathrm{hPa}(\mathbf{d})$. 
Table 2. Percentage and absolute differences in African and Asian anthropogenic emissions of $\mathrm{CO}, \mathrm{NO}_{\mathrm{x}}$ and VOCs between the AMMA and IPCC RCP45 emission scenario for 2030.

\begin{tabular}{lrr}
\hline Species & Difference over Africa & Difference over Asia \\
\hline $\mathrm{CO}$ & $+150 \%\left(85 \mathrm{Tg}(\mathrm{CO}) \mathrm{yr}^{-1}\right)$ & $+70 \%\left(145 \mathrm{Tg}(\mathrm{CO}) \mathrm{yr}^{-1}\right)$ \\
\hline $\mathrm{NO}_{\mathrm{x}}$ & $+18 \%\left(0.5 \mathrm{Tg}(\mathrm{N}) \mathrm{yr}^{-1}\right)$ & $+65 \%\left(3.8 \mathrm{Tg}(\mathrm{N}) \mathrm{yr}^{-1}\right)$ \\
\hline $\mathrm{VOCs}$ & $-0.1 \mathrm{Tg}(\mathrm{C}) \mathrm{yr}^{-1}$ & $+73 \%\left(19.5 \mathrm{Tg}(\mathrm{C}) \mathrm{yr}^{-1}\right)$ \\
\hline
\end{tabular}

Aghedo et al., 2007) and their spatial distribution. Whilst, present-day anthropogenic emissions appear to have a small influence on $\mathrm{O}_{3}$, they may increase in the near future, in particular over Africa and Asia, according to IPCC AR5 emissions scenarios. This is examined further in Sect. 6.

\subsection{Influence of Asian emissions}

In the ASIA_red run, all anthropogenic, biogenic and BB emissions were reduced by $20 \%$ over South-East Asia $\left(5^{\circ} \mathrm{S}-\right.$ $32.5^{\circ} \mathrm{N}, 67.5^{\circ} \mathrm{E}-123^{\circ} \mathrm{E}$ ). Figure 11 shows the influence of Asian emissions on $\mathrm{CO}$ concentrations in the UTLS which, due to its lifetime of 1-2 months, can be used as a tracer of polluted air masses. Changes in $\mathrm{CO}$ mixing ratios of up to $12 \mathrm{ppbv}$ and $8 \mathrm{ppbv}$ are calculated, respectively, over the convective regions of South-East Asia and over the MiddleEast and East Africa. The impact extends into the eastern part of West Africa where $\mathrm{CO}$ changes of 2 to 4 ppbv are calculated above $180 \mathrm{hPa}$. This extension of the Asian pollution influence is due to the TEJ which is stronger at and above $180 \mathrm{hPa}$ and which leads to westward transport of air masses from Asia. Barret et al. (2008) and Law et al. (2010) also established that westward transport of such air masses by the TEJ contributes to CO in the TTL over West Africa. Using a CO-like tracer defined over Asia, Stohl et al. (2002) and Lawrence et al. (2003) demonstrated that at $200 \mathrm{hPa}$ the TEJ transports tracer from southern Asia westward to the Atlantic Ocean during the summer period in Asia. The ASIA_red results show that the highest contribution of Asian polluted air masses to $\mathrm{O}_{3}$ over West Africa occurs in the TTL (Fig. 12) where maximum changes of 2 to 4 ppbv are calculated at $100 \mathrm{hPa}$. At this altitude, the influence on $\mathrm{O}_{3}$ extends into Central Africa and further downwind over the Atlantic Ocean.

\subsection{Ozone changes normalized per unit emission}

Further analysis of the $\mathrm{O}_{3}$ sensitivity experiments is presented in this section since the $20 \%$ perturbations lead to different reductions in emissions in terms of absolute amounts (in Teragrams) between the different runs (for example $\mathrm{NO}_{\mathrm{x}}$ emissions from lightning and soils or $\mathrm{CO}$ from $\mathrm{BB}$ and anthropogenic emissions). Here, we normalize the resulting average global $\mathrm{O}_{3}$ change $\left(\Delta \mathrm{O}_{3}\right)$ with respect to the amount of $\mathrm{NO}_{\mathrm{x}}$ emissions $(\mathrm{TgN})$ reduced by the $20 \%$ perturbation $\left(\Delta \mathrm{O}_{3} / \Delta \mathrm{Tg} \mathrm{N}\right)$. Figure 13 shows these normalized results as a function of altitude and longitude calculated for each sensitivity test (except BIO_red) and averaged over JJA and between $20^{\circ} \mathrm{S}$ and $20^{\circ} \mathrm{N}$. It can be seen that the LiNOx_red and BB_red simulations show the highest fraction of $\mathrm{O}_{3}$ change (up to $9 \mathrm{ppbv} \mathrm{Tg}^{-1} \mathrm{~N}$ and $8 \mathrm{ppbv} \mathrm{Tg}^{-1} \mathrm{~N}$ respectively) while lower changes (up to $5 \mathrm{ppbv} \mathrm{Tg}^{-1} \mathrm{~N}$ ) are calculated in SNOx_red, ASIA red and ANTH_red. The results suggest a larger sensitivity of $\mathrm{O}_{3}$ concentrations to changes in $\mathrm{NO}_{\mathrm{x}}$ emissions from lightning and $\mathrm{BB}$ compared to other emissions in the model. One explanation for this different response is that lightning and $\mathrm{BB} \mathrm{NO}_{\mathrm{x}}$ emissions are concentrated in the UT and LT, respectively. In contrast, anthropogenic and soil $\mathrm{NO}_{\mathrm{x}}$ emissions, which occur in convective regions during the monsoon, are redistributed throughout the troposphere by deep convection over West Africa. Convective mixing with air masses containing higher water vapour during convective uplift may also lead to $\mathrm{O}_{3}$ destruction. This could explain the higher $\mathrm{O}_{3}$ production potential from lightning and $\mathrm{BB} \mathrm{NO}_{\mathrm{x}}$ emissions. Import of emissions from Asia also makes a significant contribution to $\mathrm{O}_{3}$ over West Africa in the UT. The normalized results show a negative gradient from east to west in these $\mathrm{O}_{3}$ changes with higher changes over Asia and lower changes over West Africa. This westward decrease in $\mathrm{O}_{3}$ perturbation will also be influenced by mixing of Asian air masses with less polluted air uplifted over marine regions or forested regions over West Africa.

In order to make a relative comparison between the BIO_red simulation, where only VOC emissions were reduced, and the other tests which also included VOC or $\mathrm{CO}$ reductions, Fig. 14 shows $\mathrm{O}_{3}$ changes normalized by changes in carbon emissions due to the $20 \%$ perturbations $\left(\Delta \mathrm{O}_{3} / \Delta \mathrm{Tg} \mathrm{C}\right)$. As expected, normalized $\mathrm{O}_{3}$ changes in BIO red occur mainly in the LT but also above $200 \mathrm{hPa}$ and downwind where maximum changes of up to $0.26 \mathrm{ppbv} \mathrm{Tg}^{-1} \mathrm{C}$ are calculated. This is comparable to BB_red $\left(0.3 \mathrm{ppbv} \mathrm{Tg}^{-1} \mathrm{C}\right)$ in the $\mathrm{LT}$ but is higher than ASIA_red results over West Africa (around $0.2 \mathrm{ppbv} \mathrm{Tg}^{-1} \mathrm{C}$ ). The maximum ozone changes in BIO_red occur over a larger region $\left(20^{\circ} \mathrm{W}\right.$ to $\left.20^{\circ} \mathrm{E}\right)$ than ANTH_red. Therefore, even if they occur at different altitudes, the $\mathrm{O}_{3}$ changes due to biogenic VOC emissions are as important as the changes due to $\mathrm{BB}$ emissions. They also make a more significant contribution compared to Asian or anthropogenic emissions (based on normalizing against VOC totals).

This analysis allows us to conclude that the influence of emissions on $\mathrm{O}_{3}$ is found both over the continent and downwind over the Atlantic Ocean. The emissions primarily influencing $\mathrm{O}_{3}$ over Equatorial Africa are lightning $\mathrm{NO}_{\mathrm{x}}$ and BB. However, the results vary with altitude. In the LT, BB emissions make the largest contribution over Central Africa while soil $\mathrm{NO}_{\mathrm{x}}$ and biogenic emissions dominate over West Africa. Anthropogenic emissions also contribute, albeit to 

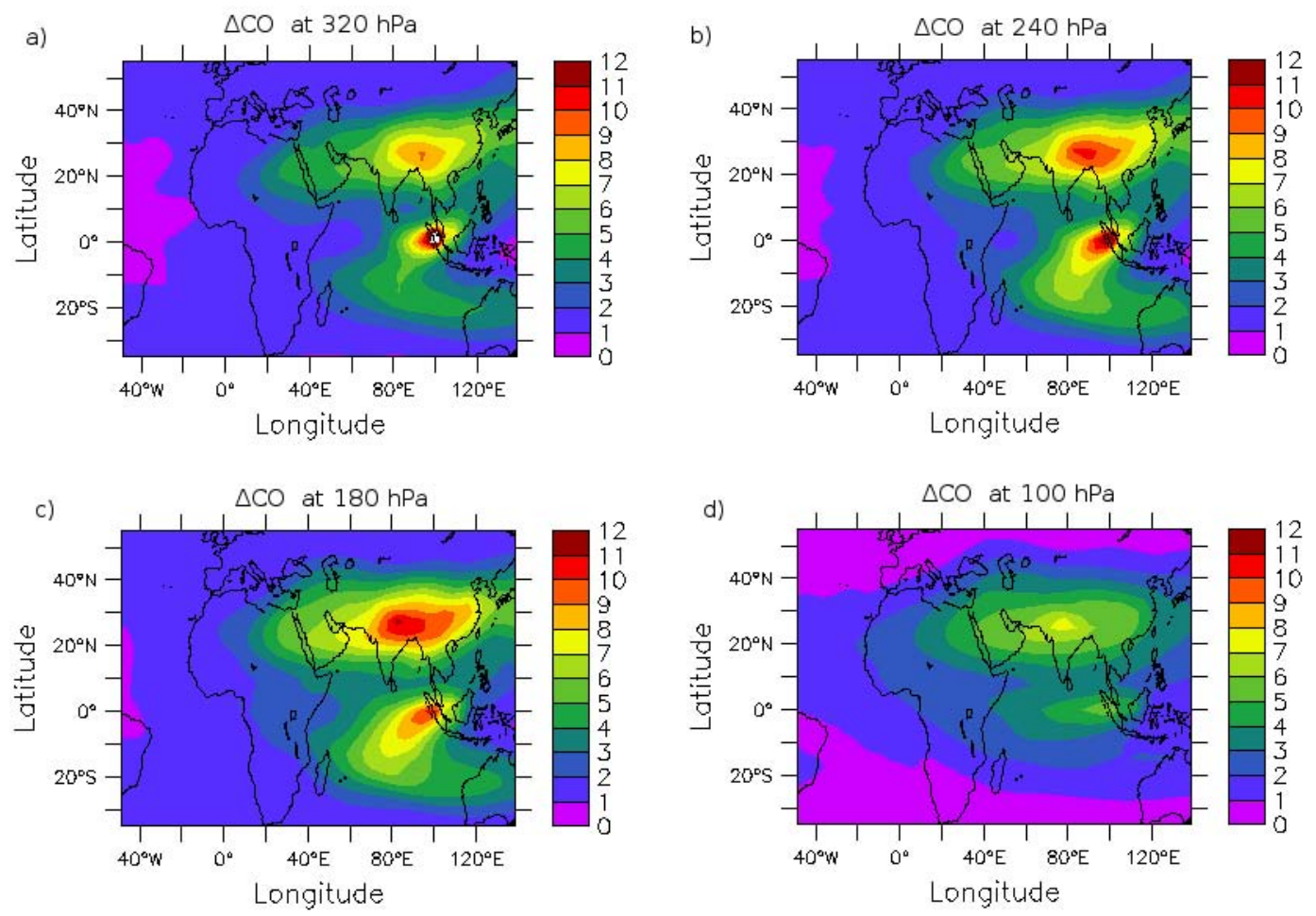

Fig. 11. KE_AMMA - ASIA_red CO differences $(\triangle \mathrm{CO})$ in ppbv at $320 \mathrm{hPa}(\mathbf{a}), 240 \mathrm{hPa}(\mathbf{b}), 180 \mathrm{hPa}$ (c) and $100 \mathrm{hPa}(\mathbf{d})$.
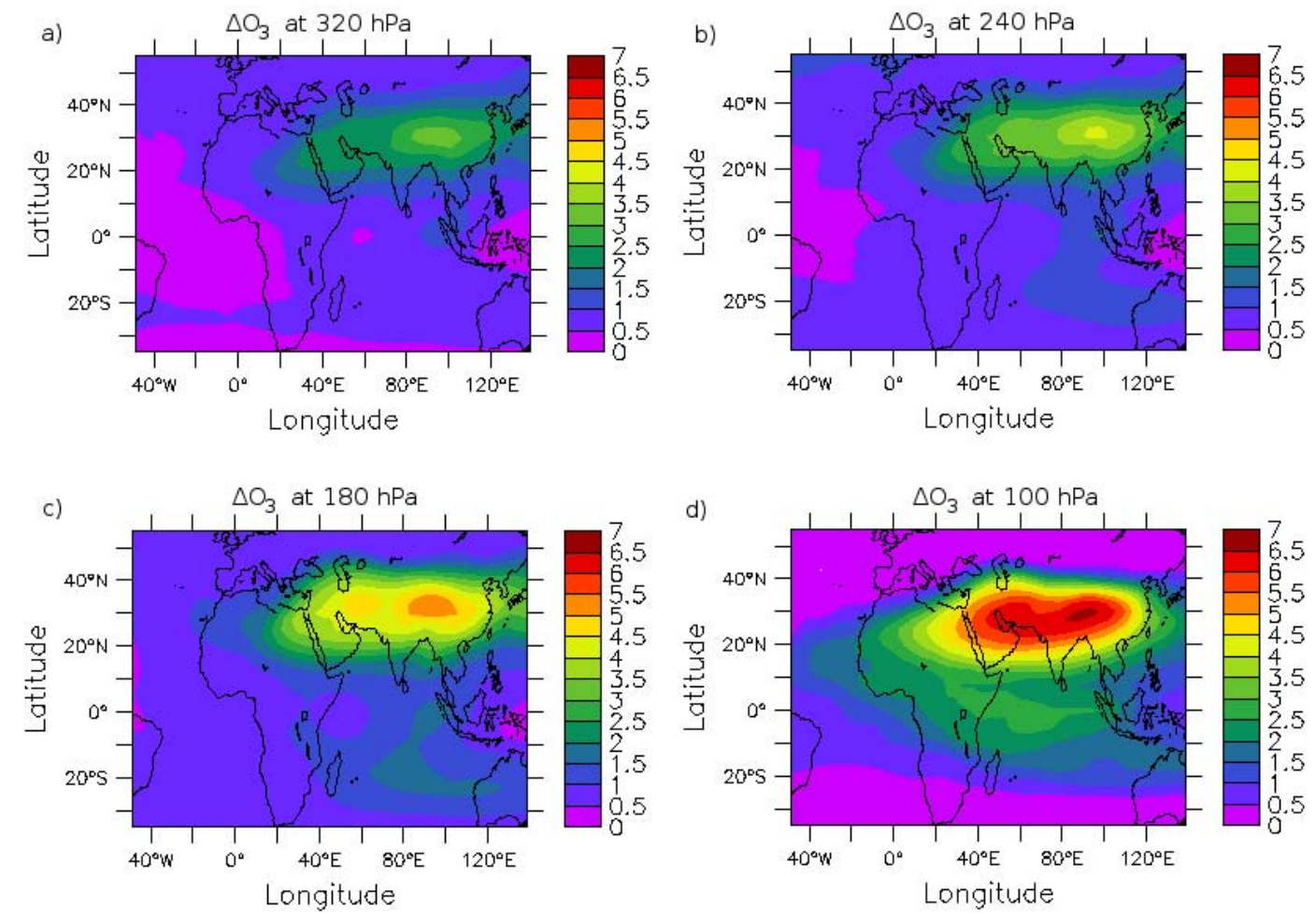

Fig. 12. Same as Fig. 11 but for $\mathrm{O}_{3}$ differences $\left(\Delta \mathrm{O}_{3}\right)$. 

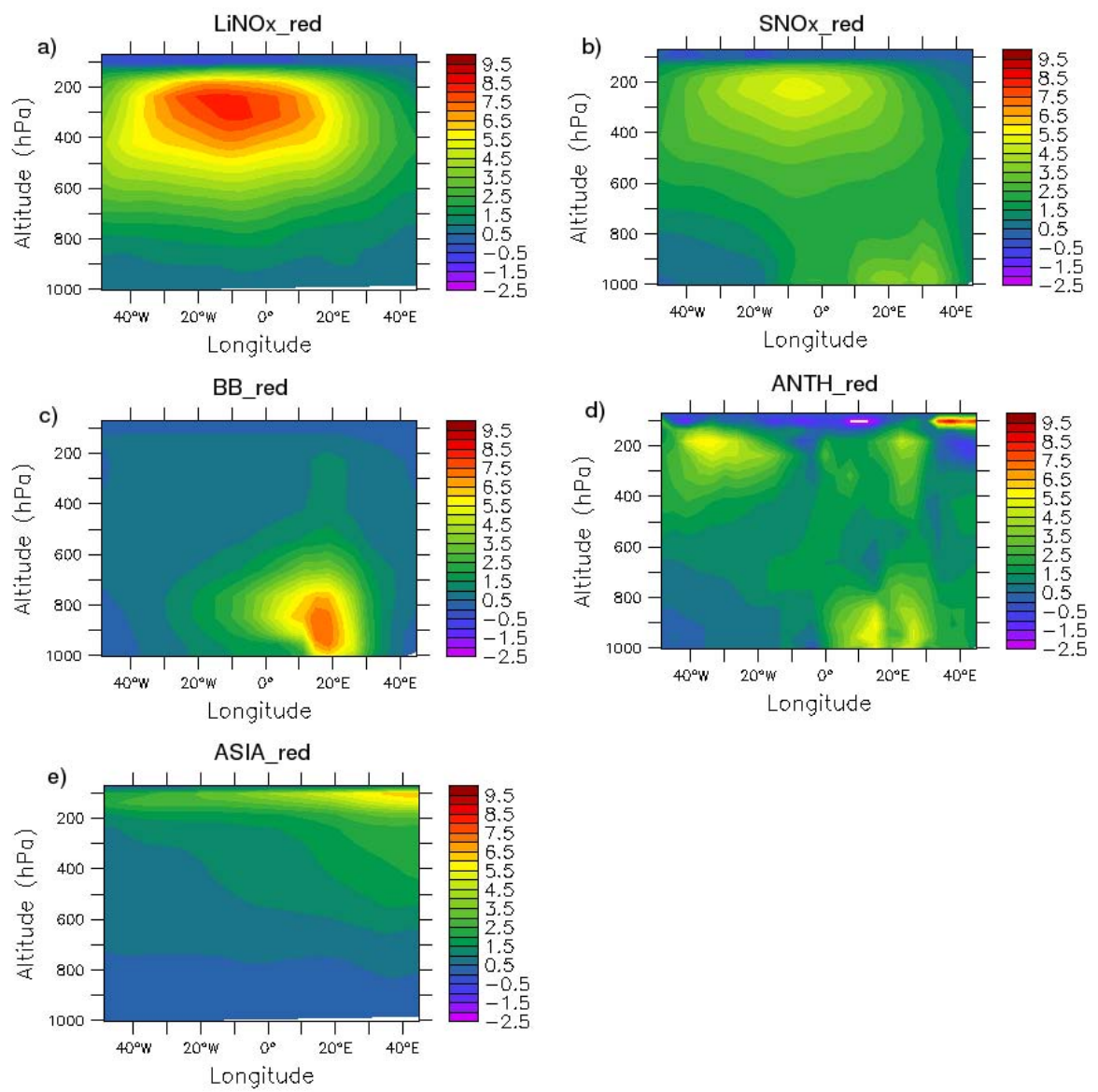

Fig. 13. Ozone difference per unit in $\mathrm{NO}_{\mathrm{x}}$ emissions $\left(\Delta \mathrm{O}_{3} / \Delta \mathrm{Tg} \mathrm{N}\right)$ between $\mathrm{KE} \_A M M A$ and the $\mathrm{LiNO}_{\mathrm{x}} \_$red $(\mathbf{a})$, $\mathrm{SNO} \mathrm{x}_{\mathrm{x}}$ red $(\mathbf{b})$, BB_red (c). ANTH_red (d) and ASIAred (e) simulationns. Ozone changes averaged between June and August and over the $20^{\circ} \mathrm{S}-20^{\circ} \mathrm{N}$ latitudinal band.

a lesser extent, to $\mathrm{O}_{3}$ in the LT over the high emission regions (e.g. Nigeria). In the MT, BB emissions also make the largest contribution to $\mathrm{O}_{3}$ particularly over Central Africa and the Atlantic Ocean at altitudes lower than $600 \mathrm{hPa}$. Between $600 \mathrm{hPa}$ and $400 \mathrm{hPa} \mathrm{O}_{3}$ is mainly influenced by lightning and soil $\mathrm{NO}_{\mathrm{x}}$ over West Africa. Lightning $\mathrm{NO}_{\mathrm{x}}$ dominates $\mathrm{O}_{3}$ changes in the UT and has an impact over a large region extending from West Africa as far as the Brazilian coast. Significant but lower contributions are also found from soil $\mathrm{NO}_{\mathrm{x}}$ and anthropogenic emissions. Biogenic VOC and Asian emissions have their largest impact on $\mathrm{O}_{3}$ in the UTLS over the African continent with only a small impact downwind over the Atlantic Ocean in the case of Asian emissions. In the model, BB emissions are not being transported far enough to the north to convective regions (as discussed in Sect. 4.2) leading to a lower UT contribution from this source. This could also be explained by the underestimation of $\mathrm{O}_{3}$ production from the Central African BB emissions in the model.
Table 3. Integrated $\mathrm{CO}$ and $\mathrm{NO}_{\mathrm{x}}$ biomass burning emission totals over Africa in the L3JRC and GFEDv2 inventories per year and during the JJA period. See text for details.

\begin{tabular}{lrr}
\hline Species & L3JRC & GFEDv2 \\
\hline $\mathrm{CO}$ & $282.6 \mathrm{Tg}(\mathrm{CO}) \mathrm{yr}^{-1}$ & $150.3 \mathrm{Tg}(\mathrm{CO}) \mathrm{yr}^{-1}$ \\
& $154.9 \mathrm{Tg}(\mathrm{CO}) / \mathrm{JJA}$ & $46.4 \mathrm{Tg}(\mathrm{CO}) / \mathrm{JJA}$ \\
\hline $\mathrm{NO}_{\mathrm{x}}$ & $6.2 \mathrm{Tg}(\mathrm{N}) \mathrm{yr}^{-1}$ & $2.4 \mathrm{Tg}(\mathrm{N}) \mathrm{yr}^{-1}$ \\
& $3.2 \mathrm{Tg}(\mathrm{N}) / \mathrm{JJA}$ & $0.77 \mathrm{Tg}(\mathrm{N}) / \mathrm{JJA}$ \\
\hline
\end{tabular}

\section{Tropospheric ozone over Africa in 2030}

In this section we investigate the possible changes in $\mathrm{O}_{3}$ in 2030 due to future growth in African and Asian anthropogenic emissions using estimates developed for the IPCC AR5 report. The anthropogenic emissions in the INCA_2030 run (see Table 1) were based on the representative concentration pathway (RCP) RCP45 scenario (Clarke et al., 2007) 

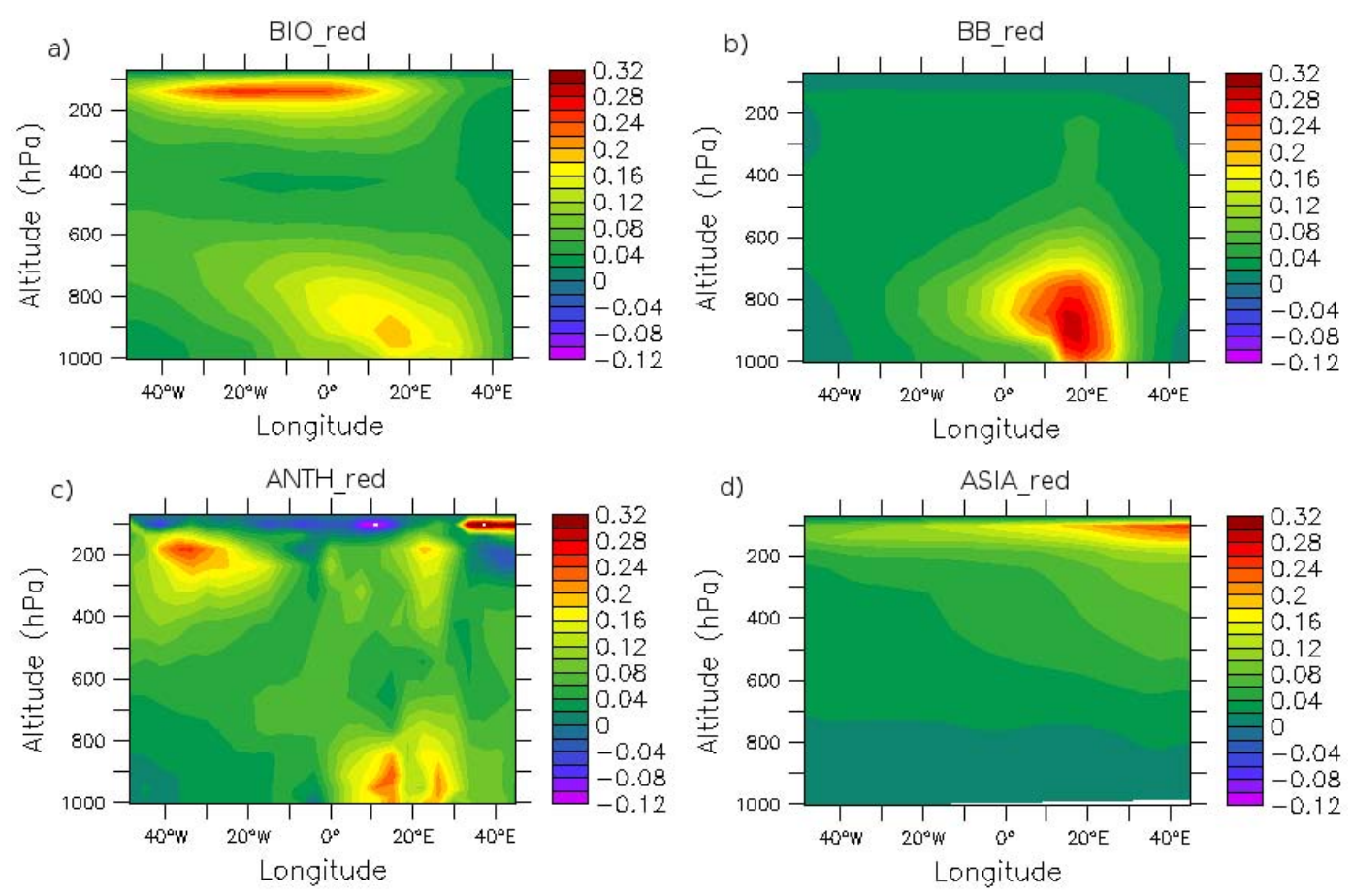

Fig. 14. Ozone difference per unit difference in carbon emissions $\left(\Delta \mathrm{O}_{3} / \Delta \mathrm{Tg} \mathrm{C}\right)$ between $\mathrm{KE} \_\mathrm{AMMA}$ and the BIO_red (a), BB_red (b), ANTH_red (c) and Asia_red simulations. Ozone changes averaged between June and August and over the $20^{\circ} \mathrm{S}-20^{\circ} \mathrm{N}$ latitudinal band.

designed to limit global warming to $4.5 \mathrm{Wm}^{-2}$. We used 2006 meteorology to ensure that possible changes are only due to changes in emissions. The most important emission changes (Table 2) occur over Asia where increases of $70 \%$, $65 \%$ and $73 \%$ in emissions of $\mathrm{CO}, \mathrm{NO}_{\mathrm{x}}$ and VOCs, respectively, are calculated. Over Africa, $\mathrm{CO}$ and $\mathrm{NO}_{\mathrm{x}}$ emissions increase significantly by $150 \%$ and $18 \%$, respectively, while there are no significant changes in VOC emissions, according to this scenario.

Figure 15 shows absolute and percentage differences in $\mathrm{CO}$ and $\mathrm{O}_{3}$ between present day (KE_AMMA) and future (INCA_2030) runs. CO increases of up to $24 \mathrm{ppbv}$ and 15 ppbv are calculated over Africa in the LT and UT, respectively. Percentage differences show that the most important CO changes (10 to $20 \%$ ) occur in the UT above $400 \mathrm{hPa}$ with maxima over East Africa above $200 \mathrm{hPa}$. Interestingly, the largest $\mathrm{O}_{3}$ changes ( 3 to 5 ppbv) also occur in UT over East Africa while lower changes ( 2 to 3 ppbv) occur over West Africa. Lower $\mathrm{O}_{3}$ increases (less than 1 ppbv) are predicted in the LT. The east-west negative gradient in $\mathrm{CO}$ and $\mathrm{O}_{3}$ increases in the UTLS calculated in INCA_2030 shows that future $\mathrm{O}_{3}$ over West Africa may be highly sensitive to increasing Asian emissions. Therefore, according to LMDz_INCA results, $\mathrm{O}_{3}$ over tropical Africa will be more sensitive to the growth of anthropogenic emissions in Asia than in Africa, at least up to 2030. Since the largest changes occur in the UT this has implications for radiative forcing estimates from tropospheric ozone. Other models may show different sensi- tivities and results will depend not only on deep convection over Africa but also on convective uplift of $\mathrm{O}_{3}$ precursors over Asia related to the Asian summer monsoon.

\section{Conclusions}

In this study, the global chemistry-climate model LMDz_INCA was used to investigate the contribution of African and Asian emissions to tropospheric ozone over Equatorial Africa during the monsoon season. In order to evaluate model performance, simulations were compared to in-situ measurements from the AMMA and MOZAIC programs as well as to satellite data from MOPITT and SCIAMACHY. The model is able to reproduce the main features of the chemical composition of the African troposphere. However, due to a low northward transport of Central African biomass burning emissions in the model, the maximum concentrations of $\mathrm{CO}$ and $\mathrm{O}_{3}$ seen in the middle troposphere over the Gulf of Guinea are reproduced further south around $0-5^{\circ} \mathrm{S}$. Model transport of $\mathrm{BB}$ emissions from Central to West Africa may be improved using more recent meteorological analyses including additional AMMA observations. Improved treatment of injection heights of BB emissions could also improve model results in the middle troposphere over the Gulf of Guinea and increase the westward export of these emissions out of Central Africa.

Uplift of air masses from the lower troposphere by deep convection and production of $\mathrm{NO}_{\mathrm{x}}$ from lightning 

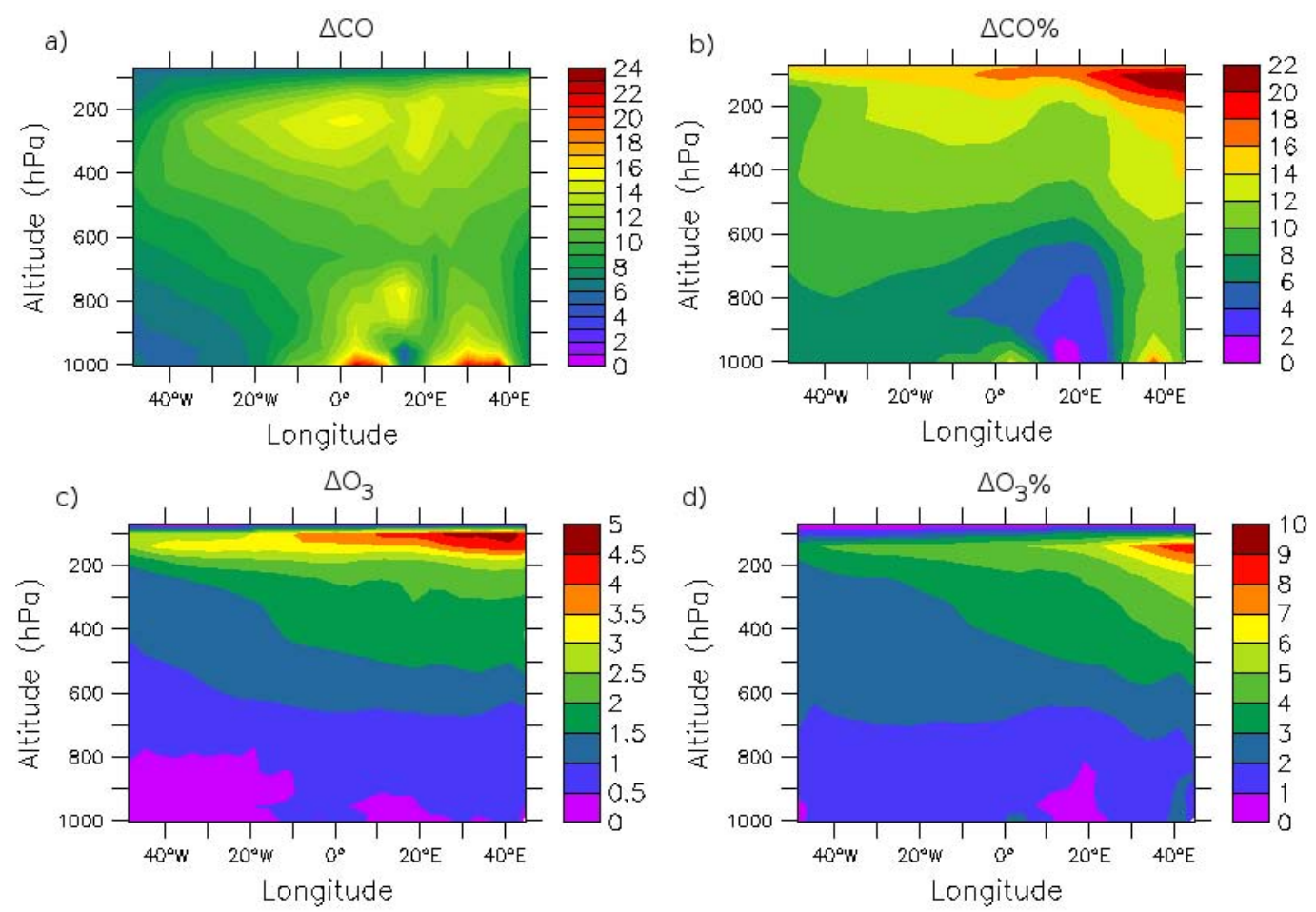

Fig. 15. Differences in ppbv (left) and percentage differences (right) in $\mathrm{CO}$ (a, b) and $\mathrm{O}_{3}$ (c, d) between KE_AMMA and INCA_2030 averaged between June and August and over the $20^{\circ} \mathrm{S}-20^{\circ} \mathrm{N}$ latitudinal band.

significantly impact the chemical composition of the upper troposphere over Africa. Observed concentrations of $\mathrm{CO}$ and $\mathrm{NO}_{\mathrm{x}}$ in the upper troposphere show higher variability in air masses influenced by convection, as well as high NO due to lightning emissions or uplift of soil $\mathrm{NO}_{\mathrm{x}}$ emissions, while uplift of $\mathrm{O}_{3}$ poor air from forested regions in southern-west Africa reduces $\mathrm{O}_{3}$ in the upper troposphere. Observed $\mathrm{NO}_{\mathrm{x}}$ profiles are underestimated by the model in the upper troposphere, especially in air masses influenced by convection. Increasing lightning $\mathrm{NO}_{\mathrm{x}}$ production in the model by $50 \%$ over Africa improves the agreement. Convective uplift of Central African biomass burning emissions also contributes significantly to the chemical composition of the upper troposphere. The model overestimates $\mathrm{CO}$ in the upper troposphere due to either strong intensity of convective updrafts and detrainment in the Emanuel scheme or to overestimation of BB emissions in the L3JRC inventory. Comparisons against MOZAIC O measurements show that the model is in fairly good agreement with the observations in the upper troposphere north of $5^{\circ} \mathrm{N}$, while concentrations are underestimated south of the equator. This discrepancy could be due to a combination of weak lightning $\mathrm{NO}_{\mathrm{x}}$ emissions and weak photochemical $\mathrm{O}_{3}$ production in uplifted $\mathrm{BB}$ emissions in the model. Increasing the lightning $\mathrm{NO}_{\mathrm{x}}$ production by $50 \%$ over Africa improves the agreement with MOZAIC data south of the equator.
Different emission sensitivity studies were performed to assess their impact on $\mathrm{O}_{3}$ over Equatorial Africa. While the main $\mathrm{O}_{3}$ changes in the lower troposphere due to African emissions occur over the continent, the highest changes in the middle and upper troposphere are found downwind over the Atlantic Ocean as a result of westward transport of continental air by the AEJ and TEJ, respectively. The results show that biomass burning and lightning $\mathrm{NO}_{\mathrm{x}}$ emissions are the main sources contributing to ozone over Equatorial Africa during the monsoon season. Lightning $\mathrm{NO}_{\mathrm{x}}$ has largest impact in the upper troposphere while biomass burning emissions mainly influence the middle and the lower troposphere. However, other emissions also have a significant contribution at certain altitudes. While biomass burning emissions have the highest impact over Central Africa, biogenic VOCs and soil $\mathrm{NO}_{\mathrm{x}}$ are the main emissions contributing to $\mathrm{O}_{3}$ over West Africa in the lower troposphere. Soil $\mathrm{NO}_{\mathrm{x}}$ emissions also contribute significantly to $\mathrm{O}_{3}$ in the upper troposphere. We have also shown that Asian emissions as well as African biogenic VOCs are the main sources contributing to $\mathrm{O}_{3}$ in the upper troposphere - lower stratosphere. Compared to other categories, anthropogenic emissions have the lowest impact on $\mathrm{O}_{3}$. By using anthropogenic emission estimates for 2030 we have shown that, according to model simulations, $\mathrm{O}_{3}$ over Equatorial Africa in the future may be more affected by the growth in Asian than in African emissions. Further 
assessment of future emission changes is required to confirm these results which are also sensitive to models treatments of chemistry and transport, particularly deep convection over monsoon regions.

Acknowledgements. The authors acknowledge the AMMA-EU and $\mathrm{SCOUT}-\mathrm{O}_{3}$ projects for support and funding. AMMA was built by an international scientific group and was funded by a large number of agencies, especially from France, the UK, US and Africa. Detailed information on scientific coordination and funding is available on the AMMA International web site at www.amma-international.org. Computer time has been provided by the Institut du Développement et des Ressources en Informatique Scientifique (IDRIS). We acknowledge FAAM for operating the BAe-146. We also acknowledge the RETRO EU and GEIA projects for providing emissions used in this study. MOZAIC is presently funded by INSU-CNRS (France), Meteo-France, and Forschungszentrum (FZJ, Jülich, Germany). The MOZAIC data base is supported by ETHER (CNES and INSU-CNRS). We are also grateful for F. Fierli for providing information about the air masses impacted by convection which were sampled by the M55 aircraft during the AMMA campaign. The M55 Geophysica data were collected as part of the EU AMMA and $\mathrm{SCOUT}_{3} \mathrm{O}_{3}$ projects.

Edited by: M. Kanakidou

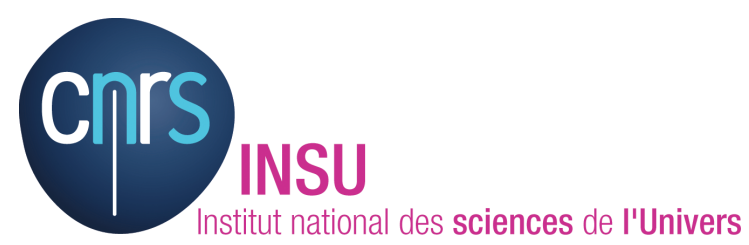

The publication of this article is financed by CNRS-INSU.

\section{References}

Aghedo, A. M., Schultz, M. G., and Rast, S.: The influence of African air pollution on regional and global tropospheric ozone, Atmos. Chem. Phys., 7, 1193-1212, doi:10.5194/acp-7-11932007, 2007.

Ancellet, G., Leclair de Bellevue, J., Mari, C., Nedelec, P., Kukui, A., Borbon, A., and Perros, P.: Effects of regional-scale and convective transports on tropospheric ozone chemistry revealed by aircraft observations during the wet season of the AMMA campaign, Atmos. Chem. Phys., 9, 383-411, doi:10.5194/acp-9-3832009, 2009.

Andrés-Hernández, M. D., Kartal, D., Reichert, L., Burrows, J. P., Meyer Arnek, J., Lichtenstern, M., Stock, P., and Schlager, H.: Peroxy radical observations over West Africa during AMMA 2006: photochemical activity in the outflow of convective systems, Atmos. Chem. Phys., 9, 3681-3695, doi:10.5194/acp-93681-2009, 2009.

Atkinson, R.: Atmoshperic chemistry of VOCs and $\mathrm{NO}_{\mathrm{x}}$, Atmos. Environ., 34, 2063-2101, 2000.

Barret, B., Ricaud, P., Mari, C., Attié, J.-L., Bousserez, N., Josse, B., Le Flochmoën, E., Livesey, N. J., Massart, S., Peuch, V.H., Piacentini, A., Sauvage, B., Thouret, V., and Cammas, J.-
P.: Transport pathways of CO in the African upper troposphere during the monsoon season: a study based upon the assimilation of spaceborne observations, Atmos. Chem. Phys., 8, 3231-3246, doi:10.5194/acp-8-3231-2008, 2008.

Barret, B., Williams, J. E., Bouarar, I., Yang, X., Josse, B., Law, K., Pham, M., Le Flochmoën, E., Liousse, C., Peuch, V. H., Carver, G. D., Pyle, J. A., Sauvage, B., van Velthoven, P., Schlager, H., Mari, C., and Cammas, J.-P.: Impact of West African Monsoon convective transport and lightning $\mathrm{NO}_{\mathrm{x}}$ production upon the upper tropospheric composition: a multi-model study, Atmos. Chem. Phys., 10, 5719-5738, doi:10.5194/acp-10-57192010, 2010.

Bechara, J., Borbon, A., Jambert, C., Colomb, A., and Perros, P. E.: Evidence of the impact of deep convection on reactive Volatile Organic Compounds in the upper tropical troposphere during the AMMA experiment in West Africa, Atmos. Chem. Phys., 10, 10321-10334, doi:10.5194/acp-10-10321-2010, 2010.

Bovensmann, H., Burrows, J. P., Buchwitz, M., Frerick, J., Noel, S., Rozanov, V. V., Chance, K. V., and Goede, A. P. H.: SCIAMACHY: Mission objectives and measurement modes, J. Atmos. Sci., 56, 127-150, 1999.

Brasseur, G. P., Orlando, J. J., and Tyndall, G. S.: Atmospheric Chemistry and global Change, Oxford Uiversity Press, NY, 1999.

Clarke, L., Edmonds, J., Jacoby, H., Pitcher, H., Reilly, J., and Richels, R.: Scenarios of Greenhouse Gas Emissions and Atmospheric Concentrations, Sub-report 2.1A of Synthesis and Assessment Product 2.1 by the US Climate Change Science Program and the Subcommittee on Global Change Research, Department of Energy, Office of Biological und Environmental Research, Washington, 7 DC, USA, pp. 154, 2007.

Crutzen, P. J.: Photochemical reactions initiated by an influencing ozone in the unpolluted troposphere, Tellus, 26, 47-57, 1974.

Crutzen, P. J. and Andreae, M. O.: Biomass burning in the tropics: Impact on atmospheric chemistry and biogeochemical cycles, Science, 250, 1669-1678, 1990.

Deeter M. N., Emmons, L. K., Edwards, D. P., Gille, J. C., and Drummond, J. R.: Vertical resolution and information content of CO profiles retrieved by MOPITT, Geophys. Res. Lett., 31, L15112, doi:10.1029/2004GL020235, 2004.

Delon, C., Reeves, C. E., Stewart, D. J., Serça, D., Dupont, R., Mari, C., Chaboureau, J.-P., and Tulet, P.: Biogenic nitrogen oxide emissions from soils impact on $\mathrm{NO}_{\mathrm{x}}$ and ozone over West Africa during AMMA (African Monsoon Multidisciplinary Experiment): modelling study, Atmos. Chem. Phys., 8, 2351-2363, doi:10.5194/acp-8-2351-2008, 2008.

Dentener, F., van Weele, M., Krol, M., Houweling, S., and van Velthoven, P.: Trends and inter-annual variability of methane emissions derived from 1979-1993 global CTM simulations, Atmos. Chem. Phys., 3, 73-88, doi:10.5194/acp-3-73-2003, 2003.

Drummond J. R. and Mand, G. S.: The measurements of pollution in the troposphere (MOPITT) instrument: Overall performance and calibration requirements, J. Atmos. Ocean. Technol., 13, 314-320, 1996.

Emanuel, K. A.: A Scheme for Representing Cumulus Convection in Large-Scale Models, J. Atmos. Sci., 48, 2313-2329, 1991.

Emanuel, K. A.: A cumulus representation based on the episodic mixing model: the importance of mixing and microphysics in predicting humidity, AMS Meteorol. Monogr., 24, 185-192, 1993. 
Emmons L. K., Pfister, G. G., Edwards, D. P., Gille, J. C., Sachse, G., Blake, D., Wofsy, S., Gerbig, C., Matross, D., and Nédélec, P.: Measurements of Pollution in the Troposphere (MOPITT) validation exercises during summer 2004 field campaigns over North America, J. Geophys. Res., 112, D12S02, doi:10.1029/2006JD007833, 2007.

Emmons, L. K., Edwards, D. P., Deeter, M. N., Gille, J. C., Campos, T., Ndlec, P., Novelli, P., and Sachse, G.: Measurements of Pollution In The Troposphere (MOPITT) validation through 2006, Atmos. Chem. Phys., 9, 1795-1803, doi:10.5194/acp-91795-2009, 2009.

Ferreira, J., Reeves, C. E., Murphy, J. G., Garcia-Carreras, L., Parker, D. J., and Oram, D. E.: Isoprene emissions modelling for West Africa: MEGAN model evaluation and sensitivity analysis, Atmos. Chem. Phys., 10, 8453-8467, doi:10.5194/acp-10-84532010, 2010.

Fierli, F., Orlandi, E., Law, K. S., Cagnazzo, C., Cairo, F., Schiller, C., Borrmann, S., Di Donfrancesco, G., Ravegnani, F., and Volk, C. M.: Impact of deep convection in the tropical tropopause layer in West Africa: in-situ observations and mesoscale modelling, Atmos. Chem. Phys., 11, 201-214, doi:10.5194/acp-11201-2011, 2011.

Folberth, G. A., Hauglustaine, D. A., Lathière, J., and Brocheton, F.: Interactive chemistry in the Laboratoire de Météorologie Dynamique general circulation model: model description and impact analysis of biogenic hydrocarbons on tropospheric chemistry, Atmos. Chem. Phys., 6, 2273-2319, doi:10.5194/acp-62273-2006, 2006.

Forster, P., Ramaswamy, V., Artaxo, P., Berntsen, T., Betts, R., Fahey, D. W., Haywood, J., Lean, J., Lowe, D. C., Myhre, G., Nganga, J., Prinn, R., Raga, G. M. S., and Van Dorland, R.: Changes in atmospheric constituents and rediative forcing. Climate change 2007: The physical Scientific Basis, Cambridge University Press, Cambridge, United Kingdom and New York, NY, USA, 6pp, 2007.

Freitas, S. R., Longo, K. M., Chatfield, R., Latham, D., Silva Dias, M. A. F., Andreae, M. O., Prins, E., Santos, J. C., Gielow, R., and Carvalho Jr., J. A.: Including the sub-grid scale plume rise of vegetation fires in low resolution atmospheric transport models, Atmos. Chem. Phys., 7, 3385-3398, doi:10.5194/acp-7-33852007, 2007.

Galy-Lacaux, C., Laouali, D., Descroix, L., Gobron, N., and Liousse, C.: Long term precipitation chemistry and wet deposition in a remote dry savanna site in Africa (Niger), Atmos. Chem. Phys., 9, 1579-1595, doi:10.5194/acp-9-1579-2009, 2009.

Giorgi, F. and Chameides, W.: The Rainout Parameterization in a Photochemical Model, J. Geophys. Res., 90, 7872-7880, 1985.

Grandpeix, J.-Y. and Lafore, J.-P.: A Density Current Parameterization Coupled with Emanuel's Convection Scheme, Part I: The Models. J. Atmos. Sci., 67, 881-897, doi:10,1175/2009JAS3044.1, 2010.

Grewe, V., Tsati, E., and Hoor, P.: On the attribution of contributions of atmospheric trace gases to emissions in atmospheric model applications, Geosci. Model Dev., 3, 487-499, doi:10.5194/gmd-3-487-2010, 2010.

Hauglustaine, D. A., Hourdin, F., Jourdain, L., Filiberti, M.-A., Walters, S., Lamarque, J.-F., and Holland, E. A.: Interactive chemistry in the Laboratoire de Météorologie Dynamique general circulation model: description and background tropospheric chemistry evaluation, J. Geophys. Res., 109, 4314-4357, 2004.

Hopkins, J. R., Evans, M. J., Lee, J. D., Lewis, A. C., H Marsham, J., McQuaid, J. B., Parker, D. J., Stewart, D. J., Reeves, C. E., and Purvis, R. M.: Direct estimates of emissions from the megacity of Lagos, Atmos. Chem. Phys., 9, 8471-8477, doi:10.5194/acp9-8471-2009, 2009.

Hourdin, F. and Armengaud, A.: The use of finite-volume methods for atmospheric advection of trace species, Part I : test of various formulations in a general circulation model, Mon. Weather. Rev., 127, 822-837, 1999.

Hourdin, F., Musat, I., Bony, S., Braconnot, P., Codron, F., Dufresne, J. L., Fairhead, L., Filiberti, M. A., Friedlingstein, P., Grandpeix, J. Y., Krinnerm, G., Levan, P., Li, Z. X., and Lott, F.: The LMDZ4 general circulation model: climate performance and sensitivity to parameterized physics with emphasis on tropical convection, Clim. Dynam., 27, 787-813, 2006.

Hourdin, F., Musat, I., Grandpeix, J. Y., Polcher, J., Guichard, F., Favot, F.,, P., Boone, A., Lafore, J. P., Redelsperger, J. L., Ruti, P. M., Dell'aquila, A., Filiberti, M. A., Pham, M., Doval, T. L., Traore, Marquet, A. K., and Gallée, H.: AMMA-Model Intercomparison Project, B. Am. Meteorol. Soc., 91, 95-104, 2010.

HTAP, Hemispheric Transport of Air Pollution, Assessement report, Parte A: Ozone and Particulate Matter, United Nations Publication, 2010.

Huntrieser, H., Schlager, H., Lichtenstern, M., Stock, P., Hamburger, T., Höller, H., Schmidt, K., Betz, H.-D., Ulanovsky, A., and Ravegnani, F.: Mesoscale convective systems observed during AMMA and their impact on the $\mathrm{NO}_{\mathrm{x}}$ and $\mathrm{O}_{3}$ budget over West Africa, Atmos. Chem. Phys., 11, 2503-2536, doi:10.5194/acp-11-2503-2011, 2011.

Jacob, D. J. J.: Introduction to Atmospheric Chemistry, Princeton University Press, Princeton, New Jersey, 1999.

Jaeglé, L., Martin, R. V., Chance, K., Steinberger, L., Kurosu, T. P., Jacob, D. J., Modi, A. I., Yoboué, V., Sigha-Nkamdjou, L., and Galy-Lacaux, C.: Satellite mapping of rain-induced nitric oxide emissions from soils, J. Geophys. Res., 109, D21310, doi:10.1029/2004JD004787, 2004.

Jaeglé, L., Steinberger, L., Martin, R. V., and Chance, K.: Global partitioning of $\mathrm{NO}_{\mathrm{x}}$ sources using satellite observations: Relative roles of fossil fuel combustion, biomass burning and soil emissions, FARADAY Discuss., 130, 407-423, 2005.

Janicot, S., Thorncroft, C. D., Ali, A., Asencio, N., Berry, G., Bock, O., Bourles, B., Caniaux, G., Chauvin, F., Deme, A., Kergoat, L., Lafore, J.-P., Lavaysse, C., Lebel, T., Marticorena, B., Mounier, F., Nedelec, P., Redelsperger, J.-L., Ravegnani, F., Reeves, C. E., Roca, R., de Rosnay, P., Schlager, H., Sultan, B., Tomasini, M., Ulanovsky, A., and ACMAD forecasters team: Large-scale overview of the summer monsoon over West Africa during the AMMA field experiment in 2006, Ann. Geophys., 26, 25692595, doi:10.5194/angeo-26-2569-2008, 2008.

Jonquières, I., Marenco, A., Maalej, A., and Rohrer, F.: Study of ozone formation and transatlantic transport from biomass burning emissions over West Africa during the airborne tropospheric ozone campaigns TROPOZ I and TROPOZ II, J. Geophys. Res., 103, 19059-19073, 1998.

Jourdain, L. and Hauglustaine, D. A.: The global distribution of lightning $\mathrm{NO}_{\mathrm{x}}$ simulated on-line in a general circulation model, Phys. Chem. Earth, 26, 585-591, 2001.

Labonne, M., Bréon, F.-M., and Chevallier, F.: Injection height of 
biomass burning aerosols as seen from a spaceborne lidar, Geophys. Res. Lett., 34, L11806, doi:10.1029/2007GL029311, 2007.

Lathière, J., Hauglustaine, D. A., Friend, A. D., De NobletDucoudré, N., Viovy, N., and Folberth, G. A.: Impact of climate variability and land use changes on global biogenic volatile organic compound emissions, Atmos. Chem. Phys., 6, 2129-2146, doi:10.5194/acp-6-2129-2006, 2006.

Law, K. S., Fierli, F., Cairo, F., Schlager, H., Borrmann, S., Streibel, M., Real, E., Kunkel, D., Schiller, C., Ravegnani, F., Ulanovsky, A., D’Amato, F., Viciani, S., and Volk, C. M.: Air mass origins influencing TTL chemical composition over West Africa during 2006 summer monsoon, Atmos. Chem. Phys., 10, 10753-10770, doi:10.5194/acp-10-10753-2010, 2010.

Lawrence, M. G., Rasch, P. J., von Kuhlmann, R., Williams, J., Fischer, H., de Reus, M., Lelieveld, J., Crutzen, P. J., Schultz, M., Stier, P., Huntrieser, H., Heland, J., Stohl, A., Forster, C., Elbern, H., Jakobs, H., and Dickerson, R. R.: Global chemical weather forecasts for field campaign planning: predictions and observations of large-scale features during MINOS, CONTRACE, and INDOEX, Atmos. Chem. Phys., 3, 267-289, doi:10.5194/acp-3267-2003, 2003.

Liousse C., Guillaume B., Grégoire J. M., Konaré A., Granier C. and Mieville, A.: AMMA biomass burning (AMMABB) emission inventories for gases and particles from savannah and forest fires for the period 2000-2007, D243g report, FP6 AMMA Project no. 004089, 2008.

Liousse, C., Guillaume, B., Grégoire, J. M., Mallet, M., Galy, C., Pont, V., Akpo, A., Bedou, M., Castra, P., Dungall, L., Gardrat, E., Granier, C., Konar, A., Malavelle, F., Mariscal, A., Mieville, A., Rosset, R., Serça, D., Solmon, F., Tummon, F., Assamoi, E., Yoboué, V., and Van Velthoven, P.: Updated African biomass burning emission inventories in the framework of the AMMAIDAF program, with an evaluation of combustion aerosols, Atmos. Chem. Phys., 10, 9631-9646, doi:10.5194/acp-10-96312010, 2010.

Liu, J. J., Jones, D. B. A., Worden, J. R., Noone, D., Parrington, M., and Kar, J.: Analysis of the summertime buildup of tropospheric ozone abundances over the Middle East and North Africa as observed by the Tropospheric Emission Spectrometer instrument, J. Geophys. Res., 114, D05304, doi:10.1029/2008JD010993, 2009.

Louis, J. F.: A parametric model of vertical eddy fluxes in the atmosphere, Boundary Layer Meteo., 17, 187-202, 1979.

Marenco, A., Thouret, V., Nédélec, P., Smit, H., Helten, M., Kley, D., Karcher, F., Simon, P., Law, K., Pyle, J., Poschmann, G., Von Wrede, R., Hume, C., and Cook, T.: Measurement of ozone and water vapor by Airbus in service aircraft: The MOZAIC airborne program, an overview, J. Geophys. Res., 103, 2563125642, doi:10.1029/98JD00977, 1998.

Mari, C. H., Cailley, G., Corre, L., Saunois, M., Attié, J. L., Thouret, V., and Stohl, A.: Tracing biomass burning plumes from the Southern Hemisphere during the AMMA 2006 wet season experiment, Atmos. Chem. Phys., 8, 3951-3961, doi:10.5194/acp-8-3951-2008, 2008.

Marufu, L., Dentener, F., Lelieveld, J., Andreae, M. O., and Helas, G.: Photochemistry of the African troposphere: Influence of biomass-burning emissions, J. Geophys. Res.-Atmos., 105, 14513-14530, 2000.

Minga, A., Thouret, V., Saunois, M., Delon, C., Serça, D., Mari, C., Sauvage, B., Mariscal, A., Leriche, M., and Cros, B.: What caused extreme ozone concentrations over Cotonou in December 2005?, Atmos. Chem. Phys., 10, 895-907, doi:10.5194/acp-10895-2010, 2010.

Murphy, J. G., Oram, D. E., and Reeves, C. E.: Measurements of volatile organic compounds over West Africa, Atmos. Chem. Phys., 10, 5281-5294, doi:10.5194/acp-10-5281-2010, 2010.

Olsen, M. A., Douglass, A. R., and Schoeberl, M. R.: Estimating downward cross-tropopause ozone flux using column ozone and potential vorticity, J. Geophys. Res., 107, 4636, doi:10.1029/2001JD002041, 2002.

Park, M., Randel, W. J., Emmons, L. K., and Livesey, N. J.: Transport pathways of carbon monoxide in the Asian summer monsoon diagnosed from Model of Ozone and Related Tracers (MOZART), J. Geophys. Res., 114, D08303, doi:10.1029/2008JD010621, 2009.

Price, C. and Rind, D.: A Simple Lightning Parameterization for Calculating Global Lightning Distributions, J. Geophys. Res., 97, 9919-9933, 1992.

Real, E., Orlandi, E., Law, K. S., Fierli, F., Josset, D., Cairo, F., Schlager, H., Borrmann, S., Kunkel, D., Volk, C. M., McQuaid, J. B., Stewart, D. J., Lee, J., Lewis, A. C., Hopkins, J. R., Ravegnani, F., Ulanovski, A., and Liousse, C.: Cross-hemispheric transport of Central African biomass burning pollutants: implications for downwind ozone production, Atmos. Chem. Phys., 10, 3027-3046, doi:10.5194/acp-10-3027-2010, 2010.

Reeves, C. E., Formenti, P., Afif, C., Ancellet, G., Attié, J.-L., Bechara, J., Borbon, A., Cairo, F., Coe, H., Crumeyrolle, S., Fierli, F., Flamant, C., Gomes, L., Hamburger, T., Jambert, C., Law, K. S., Mari, C., Jones, R. L., Matsuki, A., Mead, M. I., Methven, J., Mills, G. P., Minikin, A., Murphy, J. G., Nielsen, J. K., Oram, D. E., Parker, D. J., Richter, A., Schlager, H., Schwarzenboeck, A., and Thouret, V.: Chemical and aerosol characterisation of the troposphere over West Africa during the monsoon period as part of AMMA, Atmos. Chem. Phys., 10, 7575-7601, doi:10.5194/acp-10-7575-2010, 2010.

Richter, A., Burrows, J. P., Nüß, H., Granier, C., and Niemeier, U.: Increase in tropospheric nitrogen dioxide over China observed from space, Nature, 437, 129-132, doi:10.1038/nature04092, 2005.

Rio, C., Hourdin, F., and Chédin, A.: Numerical simulation of tropospheric injection of biomass burning products by pyro-thermal plumes, Atmos. Chem. Phys., 10, 3463-3478, doi:10.5194/acp10-3463-2010, 2010.

Rodgers, C. D. and Connor, B. J.: Intercomparison of remote sounding instruments, J. Geophys. Res., 108, 4116, doi:10.1029/2002JD002299, 2003.

Saunois, M., Reeves, C. E., Mari, C. H., Murphy, J. G., Stewart, D. J., Mills, G. P., Oram, D. E., and Purvis, R. M.: Factors controlling the distribution of ozone in the West African lower troposphere during the AMMA (African Monsoon Multidisciplinary Analysis) wet season campaign, Atmos. Chem. Phys., 9, 61356155, doi:10.5194/acp-9-6135-2009, 2009.

Sauvage, B., Thouret, V., Cammas, J.-P., Gheusi, F., Athier, G., and Nédélec, P.: Tropospheric ozone over Equatorial Africa: regional aspects from the MOZAIC data, Atmos. Chem. Phys., 5, 311335, doi:10.5194/acp-5-311-2005, 2005.

Sauvage, B., Gheusi, F., Thouret, V., Cammas, J.-P., Duron, J., Escobar, J., Mari, C., Mascart, P., and Pont, V.: Medium-range midtropospheric transport of ozone and precursors over Africa: two 
numerical case studies in dry and wet seasons, Atmos. Chem. Phys., 7, 5357-5370, doi:10.5194/acp-7-5357-2007, 2007a.

Sauvage, B., Martin, R. V., van Donkelaar, A., and Ziemke, J. R.: Quantification of the factors controlling tropical tropospheric ozone and the South Atlantic maximum, J. Geophys. Res., 112, D11309, doi:10.1029/2006JD008008, 2007b.

Sauvage B., Thouret, V., Cammas, J.-P., Brioude, J., Nédélec, P., and Mari, C.: Meridional ozone gradients in the African upper troposphere, Geophys. Res. Lett., 34, L03817, doi:10.1029/2006GL028542, 2007c.

Stewart, D. J., Taylor, C. M., Reeves, C. E., and McQuaid, J. B.: Biogenic nitrogen oxide emissions from soils: impact on $\mathrm{NO}_{\mathrm{X}}$ and ozone over west Africa during AMMA (African Monsoon Multidisciplinary Analysis): observational study, Atmos. Chem. Phys., 8, 2285-2297, doi:10.5194/acp-8-2285-2008, 2008.

Stohl, A., Eckhardt, S., Forster, C., James, P., and Spichtinger, N.: On the pathways and timescales of intercontinental air pollution transport, J. Geophys. Res., 107, 4684, doi:10.1029/2001JD001396, 2002.

Sudo, K. and Akimoto, H.: Global source attribution of tropospheric ozone: Long-range transport from various source regions, J. Geophys. Res., 112, D12302, doi:10.1029/2006JD007992, 2007.

Szopa, S., Hauglustaine, D. A., and Ciais, P.: Relative contributions of biomass burning emissions and atmospheric transport to carbon monoxide interannual variability, Geophys. Res. Lett., 34, L18810, doi:10.1029/2007GL030231, 2007.

Teyssèdre, H., Michou, M., Clark, H. L., Josse, B., Karcher, F., Olivié, D., Peuch, V.-H., Saint-Martin, D., Cariolle, D., Attié, J.-L., Nédélec, P., Ricaud, P., Thouret, V., van der A, R. J., VolzThomas, A., and Chroux, F.: A new tropospheric and stratospheric Chemistry and Transport Model MOCAGE-Climat for multi-year studies: evaluation of the present-day climatology and sensitivity to surface processes, Atmos. Chem. Phys., 7, 58155860, doi:10.5194/acp-7-5815-2007, 2007.

Thouret, V., Saunois, M., Minga, A., Mariscal, A., Sauvage, B., Solete, A., Agbangla, D., Nédélec, P., Mari, C., Reeves, C. E., and Schlager, H.: An overview of two years of ozone radio soundings over Cotonou as part of AMMA, Atmos. Chem. Phys., 9, 6157-6174, doi:10.5194/acp-9-6157-2009, 2009.

Tiedtke, M.: A comprehensive mass flux scheme for cumulus parameterization in large-scale models, Mon. Weather Rev., 117, 1179-1180, 1989.

Tost, H., Jöckel, P., and Lelieveld, J.: Lightning and convection parameterisations - uncertainties in global modelling, Atmos. Chem. Phys., 7, 4553-4568, doi:10.5194/acp-7-4553-2007, 2007.

van der Werf, G. R., Randerson, J. T., Giglio, L., Collatz, G. J., Kasibhatla, P. S., and Arellano Jr., A. F.: Interannual variability in global biomass burning emissions from 1997 to 2004, Atmos. Chem. Phys., 6, 3423-3441, doi:10.5194/acp-6-3423-2006, 2006.

Van Leer, B.: Towards the ultimate conservative difference scheme: IV, A new approach to numerical convection, J. Comput. Phys., 23, 276-299, 1977. van Noije, T. P. C., Eskes, H. J., Dentener, F. J., Stevenson, D. S., Ellingsen, K., Schultz, M. G., Wild, O., Amann, M., Atherton, C. S., Bergmann, D. J., Bey, I., Boersma, K. F., Butler, T., Cofala, J., Drevet, J., Fiore, A. M., Gauss, M., Hauglustaine, D. A., Horowitz, L. W., Isaksen, I. S. A., Krol, M. C., Lamarque, J.-F., Lawrence, M. G., Martin, R. V., Montanaro, V., Müller, J.F., Pitari, G., Prather, M. J., Pyle, J. A., Richter, A., Rodriguez, J. M., Savage, N. H., Strahan, S. E., Sudo, K., Szopa, S., and van Roozendael, M.: Multi-model ensemble simulations of tropospheric $\mathrm{NO}_{2}$ compared with GOME retrievals for the year 2000, Atmos. Chem. Phys., 6, 2943-2979, doi:10.5194/acp-62943-2006, 2006.

Walmsley, J. L. and Wesely, M. L.: Modification of coded parameterizations of surface resistances to gaseous dry deposition, Atmos. Environ., 30, 1181-1188, 1996.

Wernli, B. H. and Davies, H. C.: A lagrangian-based analysis of extratropical cyclones. I: The method and some applications, Q. J. Roy. Meteorol. Soc., 123, 467-489, doi:10.1002/qj.49712353811, 1997.

Wesely, M.: Parameterization of surface resistances to gaseous dry deposition in regional-scale numerical models, Atmos. Environ., 23, 1293-1304, 1989.

Wesely, M. L. and Hicks, B. B.: A review of the current status of knowledge on dry deposition, Atmos. Environ., 34, 2261-2282, 2000.

Williams, J. E., Scheele, M. P., van Velthoven, P. F. J., Cammas, J.-P., Thouret, V., Galy-Lacaux, C., and Volz-Thomas, A.: The influence of biogenic emissions from Africa on tropical tropospheric ozone during 2006: a global modeling study, Atmos. Chem. Phys., 9, 5729-5749, doi:10.5194/acp-9-5729-2009, 2009.

Williams, J. E., Scheele, R., v. Velthoven, P., Bouarar, I., Law, K., Josse, B., Peuch, V. H., Yang, X., Pyle, J., Thouret, V., Barret, B., Liousse, C., Hourdin, F., Szopa, S., and Cozic, A.: Global Chemistry Simulations in the AMMA Multimodel Intercomparison Project, B. Am. Meteorol. Soc., 91, 611-624, doi:10.1175/2009BAMS2818.1, 2010a.

Williams, J. E., Scheele, M. P., van Velthoven, P. F. J., Thouret, V., Saunois, M., Reeves, C. E., and Cammas, J.-P.: The influence of biomass burning and transport on tropospheric composition over the tropical Atlantic Ocean and Equatorial Africa during the West African monsoon in 2006, Atmos. Chem. Phys., 10, 9797-9817, doi:10.5194/acp-10-9797-2010, 2010.

Wu, S., Duncan, B. N., Jacob, D. J., Fiore, A. M., and Wild O.: Chemical nonlinearities in relating intercontinental ozone pollution to anthropogenic emissions, Geophys. Res. Lett., 36, L05806, doi:10.1029/2008GL036607, 2009.

Yang, X., Cox, R. A., Warwick, N. J., Pyle, J. A., Carver, G. D., O'Connor, F. M., and Savage, N. H.: Tropospheric bromine chemistry and its impacts on ozone: A model study, J. Geophys. Res., 110, D23311, doi:10.1029/2005JD006244, 2005. 